\title{
Will Economic Partnership Agreements increase poverty? The case of Uganda
}

Ole Boysen \& Alan Matthews

TEP Working Paper No. 0315

June 2015

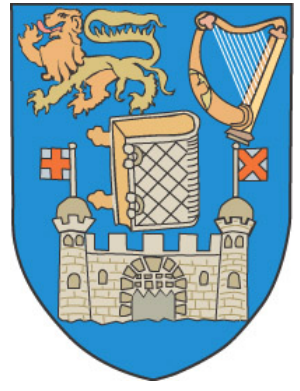

Trinity Economics Papers

\section{Department of Economics}

Trinity College Dublin 


\title{
Will Economic Partnership Agreements increase poverty? The case of Uganda*
}

\section{Ole Boysen ${ }^{\ddagger}$ and Alan Matthews ${ }^{\S}$}

May 2015

\begin{abstract}
Economic Partnership Agreements (EPAs) between the EU and ACP countries are frequently criticized because of fears about negative implications for economic development. Using Uganda as a case study, this paper employs an integrated macromicro framework rich in household-level detail to assess the consequences of the East African Community EPA for economic output and poverty. Simulations of the agreement's tariff liberalization provisions indicate very minor negative economic and poverty impacts mostly affecting the rural poor. The poverty results depend in size and direction on the way the government addresses tariff revenue losses and on labor market assumptions.
\end{abstract}

JEL classification: D58, F14, O10, O55, I32

Keywords: Economic Partnership Agreements, Uganda, poverty, trade liberalization, Computable General Equilibrium-Microsimulation

\section{Introduction}

African, Caribbean, and Pacific (ACP) countries have been negotiating Economic Partnership Agreements (EPAs) with the EU since 2002 in what has been described as a turbulent process (Hurt et al. 2013). EPAs were foreseen in the Cotonou Agreement as a replacement for the non-reciprocal trade preferences ACP countries long enjoyed on the EU market but which required a WTO waiver because they did not comply with WTO rules.

\footnotetext{
‡Ole Boysen, e-mail: boyseno@tcd.ie, Agricultural and Food Policy, University of Hohenheim, Germany and Institute for International Integration Studies, Trinity College Dublin, Ireland.

$\S$ Alan Matthews, e-mail: alan.matthews@tcd.ie, Department of Economics and Institute for International Integration Studies, Trinity College Dublin, Ireland.

*The authors wish to acknowledge financial support received under the "New Issues in Agricultural, Food and Bio-energy Trade (AGFOODTRADE)" (Small and Medium-scale Focused Research Project, Grant Agreement no. 212036) research project funded by the European Commission. The first author is grateful to the International Food Policy Research Institute (IFPRI) for facilitating access to the household survey data during an extended research stay. Furthermore, we are especially grateful to James Thurlow for providing the 2007 Uganda SAM. The views expressed in this paper are the sole responsibility of the authors and do not necessarily reflect those of the European Commission.
} 
Negotiations were due to be completed by the expiration of the WTO waiver at the end of 2007 but by this date only one EPA had been concluded - with the Caribbean ACP countries (CARIFORUM). Interim EPAs were initialed by 20 other ACP countries to allow them to benefit from duty-free and quota-free market access under the EU Market Access Regulation (EC) 1528/2007, but 43 ACP countries did not sign any agreement. These were mainly least-developed countries (LDCs) which already enjoyed duty-free access to the EU market under the Everything but Arms (EBA) arrangement. By the 1 October 2014 when the market access benefits under Regulation (EC) 1528/2007 were due to expire, comprehensive EPAs had been concluded with the Caribbean countries, West Africa, the Southern African Development Community and the East African Community (EAC) while interim EPAs continue in place with individual ACP countries in other ACP regions (European Commission, 2014). Uganda concluded its EPA negotiations with the EU on 16 October 2014 as part of the EAC. ${ }^{1}$

The ACP reluctance to sign EPAs was based on a number of fears about possible adverse effects on their economies, see, e.g., Hinkle and Schiff (2004), Bilal and Rampa (2006), Busse (2010), or Oxfam (2006). These include the possible welfare-reducing effects of trade diversion from more efficient third country suppliers to EU exporters, the possibility that more competitive EU imports would undermine local industry and lead to a process of de-industrialization, the impact of competition from subsidized EU food production on domestic food security, the potential impact of the loss of tariff revenue on EU imports for the provision of public goods and government services, the potential costs of acceding to EU demands in the areas of government procurement, investment regulations, services liberalization and intellectual property protection and, in general, the risk that these agreements would exacerbate rather than reduce overall poverty levels. Recent literature has used a variety of modeling approaches to examine these concerns, without any overall consensus emerging (see, for instance, Babula and Baltzer (2007), Bilal et al. (2012), Curran et al. (2008), Fontagne et al. (2008), ODI (2006) and the references cited therein).

In this paper, we examine a sub-set of these issues for Uganda using an integrated Computable General Equilibrium-Microsimulation (CGE-MS) model. We use the trade liberalization provisions of the interim EAC EPA which Uganda initialed in 2007, but extend the previous literature by focusing on the possible poverty impacts as well as the impacts on economic structure and welfare. Although negotiations on the comprehensive EPA were concluded in October 2014, the text was not publicly released at the time when this analysis was completed as the agreement was only being legally 'scrubbed' and pre-

\footnotetext{
${ }^{1}$ The EAC consists of Burundi, Kenya, Rwanda, Tanzania, and Uganda and formed a customs union in 2005 involving the removal of internal trade barriers (with transition rules for imports from Kenya) and the implementation of a common external tariff.
} 
pared for signature and ratification. There may be differences between the final agreed schedule of tariff liberalization and the interim agreement but we do not expect these to be major as the contentious issues in completing the agreement focused on other issues.

There is a growing literature using CGE and microsimulation models to analyze the impacts of trade liberalization on poverty, see, for instance, the studies in Hertel and Ivanic (2005), Vos et al. (2006), and Bussolo and Cockburn (2010). Our case study of Uganda adds to this literature with a careful analysis of the trade liberalization requirements agreed in the interim EU-EAC EPA. It updates and considerably improves on an earlier study by Boysen and Matthews (2010) which examined the poverty impacts of different synthetic EU-EAC EPA tariff scenarios. That study was based on older data (1999 SAM, 2002/03 household survey) and employed a sequential, top-down CGE-MS approach. It reported negligible GDP and poverty headcount effects but suggested that the hypothetical EPA scenarios which were examined would tend to decrease rural poverty while increasing urban poverty.

This study differs from the earlier one in many respects. First and foremost, the scenarios are based on the detailed interim EU-EAC EPA tariff schedule (European Commission, 2009) and 2009 trade data. It makes use of an integrated CGE-MS model rich in household-level detail, guaranteeing complete consistency between the macro and micro results and accounting for feedback effects between disaggregated household and macroeconomic levels. With regard to the poverty focus of this study, the CGE-MS model is customized to include household-specific consumption behavior and labor supply limitations as well as to represent rigidities in the labor markets and the reallocation of agricultural land. A particular contribution of this study is the explicit modeling of different scenarios regarding how the government might respond to the loss of import tariff revenue. The data sources are all updated and draw on a 2007 Uganda SAM and the nationally representative 2005/06 Ugandan National Household Survey (UNHS).

To our knowledge, three other studies have looked at the EPA's impacts on Uganda of which only one assessed poverty impacts. Milner et al. (2005) use a partial equilibrium approach, concentrating mainly on trade creation and diversion as well as welfare effects on a detailed product level. Assuming that Uganda fully liberalizes its market for EU imports, they find small positive welfare but sizable government revenue effects for Uganda. Anderson and van der Mensbrugghe (2007) study the full reciprocal liberalization between the EU and ACP countries with and without assuming free trade among all ACP countries using a multi-regional CGE model and find both cases' welfare effects to be negative but close to zero. The third study by Vollmer et al. (2009) builds on the approach of Milner et al. (2005) and uses a version of the interim EU-EAC EPA tariff schedule as a scenario. The results show a $0.2 \%$ decrease in welfare after a full implementation of the EPA and a $2.06 \%$ increase in welfare in case of a full liberalization. Based on our empir- 
ical study, we conclude that the introduction of the trade provisions of an EPA between the EAC and the EU would have minor negative effects on Ugandan GDP, government revenue, and poverty. Moreover, different government options to handle the loss of import tariff revenue have limited but possibly sign-switching impacts on the poverty results. A complete liberalization of EU imports to Uganda slightly worsens the results simulated under the standard EPA scenario. The small magnitude of the impacts is driven, in part, by the relatively low EU share of Ugandan imports and the relatively low average tariff which these imports currently face. These are comparative static results which in practice would play out over a long transition period until 2033 in which the nature of the Ugandan economy will undergo substantial change. They also do not take account of possible effects on inward investment as a result of the 'behind the border' measures agreed as part of the comprehensive EPA. These structural dynamics will likely dwarf the poverty impacts identified.

The paper proceeds as follows. The next section provides some background on the EU-EAC EPA and the links between such trade reform and poverty. Section 3 introduces the CGE-MS model and discusses some customizations which are important for our results. Section 4 presents the policy simulation scenarios and their results before Section 5 summarizes the main findings and their policy implications.

\section{Background}

The European Commission interprets the GATT Art. XXIV requirement that a regional trade agreement must liberalize "substantially all trade" to mean that $90 \%$ of the bilateral trade value must be liberalized where the liberalization can occur asymmetrically (Winters, 2008). To comply with this requirement, in the interim EPA from 3 April 2009 (European Commission, 2009) the EU commits to abolish $100 \%$ of its tariffs on EAC imports (with transitional periods for rice and sugar) whereas the EAC agrees to liberalize 82.6\% of its EU imports by value (European Commission, 2012). The EAC's tariffs on EU imports will be phased out gradually in three tranches starting in 2010 and completed in 2033; the first non-zero tariffs will be eliminated in 2015.

Due to the list of sensitive tariffs included in the EPA schedule, 23\% of Ugandan import value from the EU will remain protected enabling Uganda to retain about $70.8 \%$ of tariff revenue from EU imports. Given that its share of imports coming from the EU is about $18.7 \%$, the EPA's impacts on Ugandan government revenue will be limited. The loss in government tariff revenue amounts to $4.5 \%$ (see Section 4.1). In 2009, the share of Uganda's imports amounted to $33 \%$ of GDP. ${ }^{2}$ Altogether, these figures indicate that the

\footnotetext{
2 World Bank (2010), series "Imports of goods and services (\% of GDP)".
} 
economic shock from the EPA import tariff reductions is likely to be small.

Such a shock to import prices can be translated into poverty impacts via three main channels as identified by McCulloch et al. (2001): the consumption, the enterprise, and the government channels. Initially, import tariff changes affect the prices of imported goods and their substitutes on the domestic market. Individuals are affected as consumers when consumer prices and thereby the purchasing power of their incomes change. As producers, their profits directly depend on prices for inputs and outputs, or, as workers, price changes affect enterprise profits and thus factor demand which materializes in employment and wage changes. People are also affected as citizens when tariff revenue loss induces changes in government policies regarding direct transfers, taxes, and provision of public goods and social services. Apart from these immediate, static, monetary impacts, trade liberalization will have indirect and dynamic impacts, for instance, by increasing incentives for investment and innovation and thus economic growth as well as by altering the vulnerability of the economy and households to negative external shocks, e.g., by encouraging specialization in a smaller number of goods. Winters et al. (2004) provide a systematic framework covering all the links between trade liberalization and poverty and examine the associated theory and empirical evidence. This study concentrates on the impacts through the three static channels.

Descriptive statistics give a preliminary indication of the likely impact on poverty in Uganda through these channels. As a landlocked country with poor transport connections to seaports, Uganda faces high transport costs which provide a high degree of natural trade protection, see Milner et al. (2000). It has a high poverty rate of $31 \%$ according to official figures (in 2006, Table 6.9, UBOS, 2006) and even 52\% based on the $1.25 \$$ day poverty line (in 2005, World Bank, 2010). It is highly agriculture-centered with $73.3 \%$ of the working population working in the agriculture, forestry, and fishing sectors in 2005/06 (UBOS, 2006, Table 4.5) which account for $25 \%$ of total value added in $2009 .{ }^{3} 49.2 \%$ of Ugandan households name subsistence farming as their major source of earnings while only $20.8 \%$ name wage employment (UBOS, 2006, Table 7.3). This indicates a low dependence of household incomes on markets.

Apart from rice and wheat, Uganda is largely self-sufficient in terms of the staple foods it consumes. In fact, Uganda is an important source of food for neighboring countries. Additionally, Ugandans base their diets on a variety of staple foods of which many are not actively traded on international markets, see Benson et al.(2008). 36.7\% of household expenditures come from own production, another $11.6 \%$ from gifts received in-kind. Thus, on average, households source only a limited share of their consumption from markets. ${ }^{4}$ The five poorest deciles source $50 \%$ or less from markets and even the richest decile still

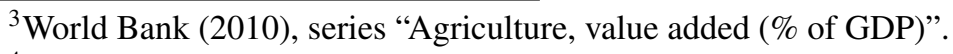

${ }^{4}$ Own computation from UNHS data. Non-marketed consumption is valued at market prices. 
sources $20 \%$ from outside the market. Therefore, impacts on consumer prices might have limited impacts on the poor's purchasing power.

Our simulation strategy builds on the fact that Uganda enjoyed preferential access to the EU market under the EU's Cotonou Agreement until end of 2007 and, since 1 January 2008, under the EU Market Access Regulation. As an LDC, Uganda is also eligible for duty-free and quota-free EU market access under the EBA scheme which will continue regardless of the conclusion of the EPA negotiations. ${ }^{5}$ We thus simplify the analysis of measuring the poverty impacts of the EPA trade provisions by examining solely the requirement that Uganda as an EAC member reduces over time its tariffs on EU imports.

Basic trade theory predicts that unilateral import tariff liberalization will increase welfare by reallocating resources to more efficient uses. This result depends on the standard assumptions regarding the operation of markets but also on the absence of other trade distortions. A preferential agreement like the EPA where only tariffs against selected importers are reduced may lead to an overall decrease in welfare due to trade diversion according to the theory of the second best (Hinkle and Schiff, 2004). Similar second-best effects may occur if a country liberalizes just some of its tariffs but maintains protection of sensitive sectors. Liberalization of the more efficient sectors can lead to production shifting to the more inefficient sectors and result in a welfare loss. Moreover, if the government replaces the import revenue loss through other taxes, the new taxes could be even more distorting leading again to a welfare loss. Thus, even the direction of the national level welfare impact of the partial liberalization expected under the EPA is not clear.

\section{Model and data}

\subsection{Model}

To facilitate the simulation of effects of economic shocks on the Ugandan economy in general as well as on incomes of individual households for poverty analysis, this study adopts a CGE-MS model ${ }^{6}$ which integrates all 7,421 households from the nationally representative UNHS 2005/06 as individual agents where each household's behavior is represented by idiosyncratic consumption and labor supply parameters.

More specifically, the CGE model used is an adaptation of the IFPRI Standard Computable General Equilibrium Model in GAMS (Löfgren et al., 2002) which is a static, non-monetary, single-country model. This choice is motivated by its excellent documentation and public availability which increase the transparency and the ease of discussing

\footnotetext{
${ }^{5}$ There has been low utilization of the EBA preferences by LDCs likely due to their more restrictive rules of origin compared to the Cotonou Agreement, see Bilal and Rampa (2006, footnote 83).

${ }^{6}$ For a comprehensive overview of methods and examples of CGE-MS studies, see, e.g., ?, Bourguignon et al. (2008) or Bussolo and Cockburn (2010).
} 
the model and the results. The reader is referred to the documentation in Löfgren et al. (2002) for an exhaustive description and mathematical formulation of the model. Only the closure assumptions and customizations are presented here.

The choice of "closures" has been guided by the goal of capturing all welfare changes in the simulations undertaken. This includes future welfare effects from saving, borrowing, and investment and non-monetary welfare provided through public goods and services. Changes in government consumption could cause unaccounted welfare effects through changed provision of public goods and services. Likewise, changes in government savings would imply unaccounted welfare effects in the future. Thus, real government consumption and nominal savings are held constant which implies that changes in import tariff revenues and price changes of publicly-provided government services (administration, education, and health services) must be offset through other sources of revenue. To this end, a general household income levy, assumed to be income distributionneutral, is introduced as a hypothetical revenue compensation instrument. The percentage point change of the tax adapts endogenously and is levied uniformly on all household incomes including consumption of own produce. In line with this argumentation, foreign savings are also assumed to remain constant requiring exchange rate adjustments to balance the current account. Similarly, investment is held constant in quantity terms and households' savings adjust by a uniform percentage change to counter changes in the domestic value of the rest of the world savings and changes in the prices of investment goods.

The way factor markets work has been modified compared to the standard IFPRI model. As the impacts of the complete implementation of the EPA in 2033 are simulated, this model works over a long time horizon. Accordingly, capital can depreciate and be reinvested in other sectors and is thus assumed to be fully mobile at a fixed supply level with rents clearing the market. Wage rates vary to clear the labor markets. But also the supplies of unskilled and skilled labor are assumed to increase with the associated real wage levels based on the so-called wage curve relationship introduced by Blanchflower and Oswald (1995). They empirically found a relationship between the level of the real wage and unemployment with an elasticity of unemployment with respect to the real wage level of approximately -0.1 valid across a large number of countries. Subsequently, this relationship and elasticity have been empirically confirmed by numerous studies for various countries, including the African countries Burkina Faso, Côte d'Ivoire, and South Africa. Nijkamp and Poot (2005) subject the findings of the wage curve literature to a meta-analysis, confirm the stability of the negative real wage to unemployment relationship, and suggest a publication-bias corrected elasticity of -0.07 . Here, an elasticity of -0.1 is adopted. While the wage curve is observed on a macro level and thus is implemented to affect the aggregate supplies of skilled and unskilled labor, respectively, 
individual households might be limited in their potential to increase (if they are fully employed) or decrease (unemployed) their labor supply. Accordingly, the labor supply of each household is modeled as being restricted from below by the state of unemployment and from above by full employment. More specifically, the labor utilization rate adapts in terms of percentage point changes uniformly for all households but some households are unaffected if their individual labor utilization rates are already at a limit. The potential for additional labor supply (un- and underemployment) of individual households has been derived from the household survey data on unemployment, inactivity, and time-related underemployment of households' members. ${ }^{7}$ The wage-weighted labor potentials suggest a current labor utilization of $79.6 \%$ and $89.1 \%$ for unskilled and skilled labor, respectively (Table 2).

Also the land market is assumed to clear through rent adjustments. As climate and soil conditions vary strongly across Uganda, crops, trees, and pastures do not grow with the same productivity in all areas. To reflect these differences in productivity when reallocating land between different crop uses, an approach presented by Keeney and Hertel (2009) is adopted. According to this, each land owner has a fixed area of land and rents it out to different activities with the goal of maximizing returns from land subject to limitations on the transformation of land from one use to another. As this limits the "mobility" of land, rents differ between sectors. Here, the model formulation consists of a two-level Constant Elasticity of Transformation (CET) function nesting structure. On level one, the land owner decides on renting to annual or perennial crops or pastures. On the second level, the owner decides on renting to a particular use within each group. The transformation of land use between the annual and perennial crop and pasture groups as well as within the perennial group is assumed to be rather sluggish with an elasticity of transformation of -0.25 . By contrast, switching land between uses for different annual crops is easier and an elasticity of transformation of -1.1 is assumed and a quasi-perfect elasticity of transformation between pastures for different livestock types of -20.

A further modification to the IFPRI model concerns imports. The composition of imports and tariffs on imports from the EU differ strongly from those from the EAC and the rest of the world. Thus, differentiation of imports and tariff rates by origin is imperative to appropriately apply the EPA import tariff provisions. To this end, the model's Constant Elasticity of Substitution (CES) import functions are augmented by second-level CES functions which aggregate imported varieties of a good from different origins to an aggregate import good depending on the import shares and after-tariff prices of each region. This assumes that domestic consumers perceive imports from different origins as

\footnotetext{
${ }^{7}$ Adopting the definition from the report on the UNHS (UBOS 2006), time-related underemployment refers to individuals from the workforce which have worked less than 40 hours per week and are willing and able to provide more labor hours.
} 
somewhat heterogeneous goods.

Finally, each household's consumption demand is determined by a linear expenditure system which is parameterized individually for the respective household by deriving its specific parameters from an econometrically estimated flexible demand system (Boysen, 2012). This introduces an additional layer of individual household behavior where CGE models commonly rely on a single set of demand elasticities for all households.

The CPI is fixed and serves as the numeraire for the model.

\subsection{Data}

The central piece of data for any CGE model is the SAM. The SAM used for this study is based on the 2007 SAM for Uganda constructed by Thurlow (2008) which is extended to include the complete set of households from the UNHS 2005/06. The final, extended Uganda SAM comprises 21 agricultural and 29 non-agricultural sectors, unskilled and skilled labor, land, and capital as factors of production, as well as accounts for an enterprise, the government, household transfers, the rest of the world, and finally 7,421 households. Note that capital includes livestock. The SAM data (based on the national accounts) and the household data (drawn from the household survey) are reconciled by a series of procedures. ${ }^{8}$ The structure of the final SAM is summarized in Table 1.

Additionally, import values and tariffs from the TRAINS database (UNCTAD, 2010) are used for disaggregating Ugandan imports by origin as well as for construction of the tariff scenarios. The tariffs for the EPA scenario are constructed from the latest official tariff schedule document available when the analysis was conducted, the interim EU-EAC EPA from April 2009 (European Commission, 2009), and represent the tariffs at the end of the implementation period in 2033.

Table 2 provides a summary of the household information contained in the SAM which is useful for the interpretation of the simulation results. The 'all' column presents means over the entire Ugandan population and the other columns show means over household groups categorized by rural versus urban locations and poverty status. A household's poverty status is determined by its per capita expenditure on consumption (PCE) as explained in the next section.

\subsection{Poverty lines and measures}

For measuring poverty, we employ an absolute poverty line and the measures $P_{\alpha}$ introduced by Foster, Greer and Thorbecke (1984). The measure is defined as $P_{\alpha}=$ $\frac{1}{N} \cdot \sum_{i=1}^{N}\left(\frac{z-y_{i}}{z}\right)^{\alpha} \cdot I_{i}$ with $N$ : population size, $z$ : poverty line, $y_{i}$ : income of individual

\footnotetext{
${ }^{8}$ Refer to the appendix for further details.
} 
Table 1: The structure of Uganda's domestic industry and trade, 2007

\begin{tabular}{|c|c|c|c|c|c|c|c|c|c|c|}
\hline & $\begin{array}{l}\text { Share in } \\
\text { total pro- } \\
\text { duction } \\
\text { value }\end{array}$ & $\begin{array}{r}\text { Share in } \\
\text { total } \\
\text { value } \\
\text { added }\end{array}$ & $\begin{array}{r}\text { Share in } \\
\text { total } \\
\text { exports }\end{array}$ & $\begin{array}{r}\text { Export } \\
\text { share in } \\
\text { output of } \\
\text { the sector }\end{array}$ & $\begin{array}{r}\text { Share in } \\
\text { total } \\
\text { imports }\end{array}$ & $\begin{array}{r}\text { Import } \\
\text { share in } \\
\text { demand } \\
\text { for com- } \\
\text { modity }\end{array}$ & $\begin{array}{r}\text { Import } \\
\text { tariff }\end{array}$ & $\begin{array}{r}\text { Share in } \\
\text { total } \\
\text { import } \\
\text { tariff } \\
\text { revenue }\end{array}$ & $\begin{array}{r}\text { Share in } \\
\text { total } \\
\text { house- } \\
\text { hold } \\
\text { home } \\
\text { con- } \\
\text { sumption }\end{array}$ & $\begin{array}{r}\text { Share in } \\
\text { total } \\
\text { house- } \\
\text { hold } \\
\text { market } \\
\text { con- } \\
\text { sumption }\end{array}$ \\
\hline Maize & 1.19 & 1.71 & 1.87 & 18.56 & 0.79 & 13.33 & 0.06 & 0.00 & 2.44 & 0.20 \\
\hline Rice & 0.25 & 0.37 & - & - & - & - & - & - & - & - \\
\hline Other cereals & 0.98 & 1.39 & 1.66 & 22.76 & 1.88 & 33.79 & 0.26 & 0.03 & 2.70 & 0.45 \\
\hline Cassava & 1.72 & 2.45 & - & - & - & - & - & - & 10.24 & 1.28 \\
\hline Irish potatoes & 0.37 & 0.29 & - & - & - & - & - & - & 1.24 & 0.29 \\
\hline Sweet potatoes & 1.88 & 2.50 & - & - & - & - & - & - & 12.34 & 0.82 \\
\hline Beans & 2.25 & 2.61 & 4.30 & 27.08 & - & - & - & - & 7.32 & 1.81 \\
\hline Vegetables & 0.59 & 0.85 & 0.04 & 0.54 & - & - & - & - & 2.57 & 2.04 \\
\hline Matooke & 2.59 & 4.05 & - & - & - & - & - & - & 15.70 & 2.44 \\
\hline Fruits & 0.67 & 0.96 & 0.13 & 4.22 & 0.08 & 4.39 & 7.85 & 0.04 & 3.80 & 0.87 \\
\hline Oil seed crops & 0.65 & 0.90 & 0.16 & 3.25 & 0.14 & 4.54 & 0.07 & 0.00 & 1.79 & 0.98 \\
\hline Cotton & 0.11 & 0.12 & 1.09 & 100.00 & - & - & - & - & - & - \\
\hline Tobacco & 0.37 & 0.53 & 3.52 & 96.55 & - & - & - & - & - & - \\
\hline Coffee & 0.75 & 0.84 & 7.41 & 100.00 & - & - & - & - & - & - \\
\hline Tea leaves & 0.23 & 0.30 & 2.28 & 100.00 & - & - & - & - & - & - \\
\hline Other export crops & 0.24 & 0.15 & 1.51 & 62.97 & - & - & - & - & - & - \\
\hline Cattle & 1.32 & 1.56 & - & - & - & - & - & - & - & - \\
\hline Poultry & 0.44 & 0.32 & 0.04 & 1.81 & 0.03 & 1.88 & 3.81 & 0.01 & 1.86 & 0.39 \\
\hline Other livestock & 0.19 & 0.28 & 0.23 & 11.32 & - & - & - & - & 0.06 & 0.43 \\
\hline Forestry & 1.76 & 2.11 & 1.56 & 8.55 & - & - & - & - & 1.23 & 4.06 \\
\hline Fish & 1.39 & 2.08 & 5.43 & 37.05 & - & - & - & - & 0.17 & 1.28 \\
\hline Grain milling & 1.91 & 0.60 & - & - & 1.06 & 8.59 & 8.63 & 0.58 & 3.93 & 4.11 \\
\hline Meat & 1.40 & 0.12 & 0.68 & 4.07 & 0.79 & 7.06 & 0.40 & 0.02 & 3.42 & 5.10 \\
\hline Fish p & 0.73 & 0.10 & 5.67 & 58.30 & 0.55 & 13.31 & 1.96 & 0.07 & 0.04 & 0.91 \\
\hline Othe & 2.90 & 0.89 & 8.12 & 23.85 & 4.02 & 18.53 & 6.86 & 1.75 & 0.60 & 6.38 \\
\hline feed pro & 0.34 & 0.12 & - & - & - & - & - & - & - & - \\
\hline Beve & 1.09 & 0.50 & 0.49 & 3.54 & 1.00 & 10.48 & 9.74 & 0.62 & 0.58 & 3.30 \\
\hline Text & 0.85 & 0.64 & 1.85 & 11.11 & 3.64 & 21.07 & 12.84 & 2.97 & 0.06 & 5.48 \\
\hline Wood \& paper products & 0.39 & 0.17 & 0.09 & 2.11 & 1.66 & 38.38 & 10.57 & 1.11 & - & 0.27 \\
\hline Mining & 0.23 & 0.30 & 0.67 & 21.85 & 0.96 & 33.36 & 8.31 & 0.51 & - & - \\
\hline Fuels & 0.08 & 0.01 & - & - & 6.10 & 32.91 & 175.79 & 68.19 & - & 3.16 \\
\hline Chemi & 1.35 & 0.68 & 1.17 & 6.58 & 12.53 & 45.97 & 4.95 & 3.94 & - & 4.33 \\
\hline Other & 1.59 & 1.15 & 1.31 & 7.17 & 7.89 & 38.55 & 10.87 & 5.45 & 0.00 & 1.11 \\
\hline ry \& equipment & 1.37 & 0.70 & 4.32 & 26.26 & 33.44 & 65.69 & 6.80 & 14.45 & 0.00 & 3.12 \\
\hline Furn & 0.43 & 0.31 & 0.05 & 0.95 & 0.42 & 11.46 & 9.51 & 0.25 & 0.01 & 0.73 \\
\hline Utilities & 2.64 & 3.75 & 1.46 & 5.64 & - & - & - & - & - & 4.86 \\
\hline Cons & 14.19 & 12.65 & - & - & - & - & - & - & - & 1.78 \\
\hline Trade s & 10.38 & 10.01 & - & - & - & - & - & - & 0.00 & 0.16 \\
\hline Hotels & 4.77 & 5.97 & 30.41 & 65.96 & - & - & - & - & 0.66 & 4.21 \\
\hline Transport services & 3.19 & 3.52 & 11.04 & 35.23 & 17.15 & 58.44 & - & - & - & 4.02 \\
\hline Communication services & 1.96 & 1.82 & 0.88 & 4.57 & 0.39 & 3.41 & - & - & - & 2.56 \\
\hline $\begin{array}{l}\text { Financial \& banking ser- } \\
\text { vices }\end{array}$ & 0.89 & 0.90 & 0.26 & 3.02 & 1.80 & 26.10 & - & - & - & 0.17 \\
\hline Real estate & 6.29 & 8 & - & - & - & - & - & - & 27.09 & 3.16 \\
\hline Other private se & 1.69 & 2.36 & 0.31 & 1.90 & 3.70 & 27.51 & 0.02 & 0.00 & 0.04 & 1.48 \\
\hline Public administration & 4.88 & 4.59 & - & - & - & - & - & - & - & - \\
\hline Education & 8.98 & 9.07 & - & - & - & - & - & - & 0.00 & 10.79 \\
\hline Health & 4.38 & 3.46 & - & - & - & - & - & - & 0.05 & 8.26 \\
\hline Community services & 1.16 & 1.20 & - & - & - & - & - & - & 0.03 & 3.21 \\
\hline & .94 & o & 1.23 & 23.66 & 2.92 & 4.07 & 0.45 & 0.08 & 63.45 & 17.34 \\
\hline Non & 80.06 & 73.62 & 68.77 & 8.45 & 97.08 & 17.04 & 16.19 & 99.92 & 36.55 & 82.66 \\
\hline Total & 100.00 & 100.00 & 100.00 & 10.63 & 100.00 & 15.59 & 15.73 & 100.00 & 100.00 & 100.00 \\
\hline
\end{tabular}

Source: Own computations from the 2007 Uganda SAM. 
Table 2: Household income and spending characteristics

\begin{tabular}{|c|c|c|c|c|c|}
\hline & \multirow[b]{2}{*}{ All } & \multicolumn{2}{|c|}{ Rural } & \multicolumn{2}{|c|}{ Urban } \\
\hline & & non-poor & poor & non-poor & poor \\
\hline Mean PCE (thousand UGX) & 493.7 & 538.1 & 171.5 & $1,038.4$ & 194.9 \\
\hline Number of people (million) & 28.4 & 15.8 & 8.2 & 3.9 & 0.6 \\
\hline Share in total population & 100.0 & 55.4 & 28.8 & 13.7 & 2.1 \\
\hline Home produced share in consumption & 26.1 & 31.5 & 37.7 & 11.0 & 15.9 \\
\hline Food share in consumption & 44.1 & 48.6 & 61.8 & 28.3 & 54.1 \\
\hline Share in national household income & 100.0 & 55.2 & 8.6 & 35.2 & 1.0 \\
\hline \multicolumn{6}{|l|}{ Labor utilization rate } \\
\hline Unskilled & 79.6 & 80.0 & 68.3 & 84.1 & 76.6 \\
\hline Skilled & 89.1 & 91.8 & 91.9 & 87.3 & 62.5 \\
\hline Source of income & \multicolumn{5}{|c|}{ As share in household income $(\%)$} \\
\hline Labor unskilled & 36.0 & 36.0 & 48.0 & 32.4 & 65.2 \\
\hline Labor skilled & 12.3 & 9.2 & 1.8 & 20.2 & 2.6 \\
\hline Land & 7.7 & 10.3 & 12.9 & 2.4 & 4.7 \\
\hline Capital & 27.9 & 27.3 & 13.1 & 33.1 & 9.0 \\
\hline Transfers & 16.0 & 17.2 & 24.2 & 12.0 & 18.4 \\
\hline Application of income & \multicolumn{5}{|c|}{ As share in household income $(\%)$} \\
\hline Consumption (gross) & 74.1 & 80.0 & 83.3 & 62.7 & 65.4 \\
\hline Sales tax on consumption & 1.4 & 1.5 & 1.4 & 1.4 & 1.4 \\
\hline Income tax & 2.2 & 1.7 & 1.0 & 3.3 & 1.0 \\
\hline Transfers & 15.2 & 11.4 & 10.0 & 22.4 & 13.8 \\
\hline Saving & 7.1 & 5.4 & 4.2 & 10.2 & 18.5 \\
\hline
\end{tabular}

Source: Own computation from the SAM and the UNHS.

$i$, and $I_{i}=1$ if $y_{i}<z$ and $I_{i}=0$ otherwise.

Setting the parameter $\alpha$ to 0,1 , or 2 computes the poverty headcount, gap, or severity index, respectively. The poverty headcount index $P_{0}$ measures the percentage of people falling below the poverty line. The poverty gap $P_{1}$ measures the extent by which poor people fall under the poverty line as a percentage of the poverty line on average. The poverty severity index $P_{2}$ squares that shortfall percentage of each person before averaging and thus gives more weight to more severely affected people.

Poverty lines are derived such that they reproduce the poverty headcounts of $34.2 \%$ for rural and $13.7 \%$ for urban households reported in the UNHS Report on the SocioEconomic Survey (UBOS, 2006, Table 6.3.2 (a)) in the base simulation. This results in poverty lines of 244,079 UGX for rural and 269,057 UGX for urban households. The UBOS poverty lines are based on the cost of basic needs approach, which accounts for the cost of meeting physical calorie needs and allows for vital non-food expenditure, such as clothing and cooking fuels, valued using the average consumption basket of the poorest $50 \%$ of the population (UBOS, 2006, Section 6.3). The rural and urban poverty lines account for the differences in prices and consumption baskets of the respective subpopu- 
lations. PCE is used for assessing poverty. To calculate the PCE from the CGE-MS results for each of the 7,421 households, household consumption is measured as the sum of the values of market and home consumption of own produce (henceforth called home consumption), both valued at market prices, which then is deflated by a household-specific consumption price index (CPI) to yield real PCE. This CPI is unusual in that it values home consumption at producer prices in order to account for differing acquisition costs of items consumed.

\section{Policy simulations}

Taking into account that Uganda has had duty-free access to EU markets for some time and would continue to have this regardless of the outcome of the EPA negotiations, the simulations consider the impact of Uganda's own EPA import tariff reductions. To assess the impact of the protection which is retained through the exemptions included in the list of sensitive products of the agreement, the EPA scenario is contrasted with a full liberalization of imports from the EU. A set of fiscal policy scenarios are also described to show how the way the government chooses to respond to the loss of tariff revenue can influence the macroeconomic and poverty outcomes. Finally, acknowledging the uncertainty about how Ugandan labor markets operate in practice, we examine two alternative labor market closures to assess the sensitivity of our results in this respect.

Since the sectoral trade structure of the 2007 Uganda SAM used has been constructed using 2002/03 supply-use tables for Uganda, see Thurlow (2008), and the common external tariff of the EAC had not been fully implemented in 2002/03, we conduct a preexperiment to simulate the impacts of Uganda's implementation of the EAC customs union in 2005 including the adoption of the common external tariff and the removal of the EAC market's internal tariffs. ${ }^{9}$ The tariff patterns before and after the EAC common external tariff implementation are rather different. Tariffs on imports from the EU and the ROW are strongly increased in many sectors where Uganda previously applied low tariffs. Overall, the trade-weighted average import tariffs for the EU and the ROW rise by 4.9 and 9.7 percentage points, respectively. The results of this pre-experiment form the starting point for our EPA policy simulations. ${ }^{10}$

\footnotetext{
${ }^{9}$ Roughly, the EAC common external tariff applies a three-band import tariff structure with 0 percent on raw materials, 10 percent on intermediate products and 25 percent on finished products, complemented with a list of sensitive products for which the tariffs are higher than 25 percent.

${ }^{10}$ Detailed results for simulations mentioned but not shown are available from the authors on request.
} 


\subsection{Scenarios}

Tariff scenarios. For the EPA simulation the import tariff scenarios are built up from the detailed tariff-line information at the Harmonised System 6-digit tariff level contained in the 2009 interim agreement aggregated to the SAM sectors and the model import origins EAC, ROW, and EU by using 2003 import values. The percentage changes in the aggregated tariffs for each SAM sector calculated from the individual tariff line data are then applied as shocks to the initial implicit tariffs in the SAM. The tariffs implicit in the SAM are derived from tariff revenue actually collected rather than from the nominal tariffs as published in the official import tariff schedules. Differences between these can be due to, for example, weaknesses in the recording of trade statistics, poor collection rates as a consequence of corruption or informal cross border trade, or additional taxes not included in the TRAINS database. Due to the approach chosen, such distortions will change proportionally with the applied percentage change shock.

In addition to the EPA tariff scenario, an EU free trade scenario is specified where all EU tariffs are set to zero. The tariff scenarios are presented in Table 3 . These are based on 2009 tariff data weighted using 2003 import values, all from the TRAINS database.

Neglecting any adaptive behavior of the economy, the EPA schedule has the following direct implications. The share in EU import values entering Uganda free of tariffs increases from $53.6 \%$ to $77.0 \%$ where the remaining $23 \%$ remain protected through the list of sensitive products. Based on the model data, the average weighted tariff on EU imports drops from $8.8 \%$ to $6.3 \%$. The EU is the source of $18.7 \%$ of Ugandan imports with the most important imports from the EU being machinery \& equipment, other manufacturing, and chemicals. The weighted average tariff on agricultural and food imports from the EU (processed and unprocessed) of $31.1 \%$ drops only to $30.4 \%$ while the same variable for the remaining sectors drops from $7.2 \%$ to $4.4 \%$. Hence, almost all of the EPA shock affects the non-agricultural and non-food sectors. Altogether, the government loses $4.5 \%$ of its total revenue from import tariffs. This number is small because the list of sensitive products allows Uganda to retain about $70.8 \%$ of its tariff revenue from EU imports and because the EU is a relatively small source of Ugandan imports. By contrast, the EU free trade scenario causes a loss of government import tariff revenue of $15 \%$.

Fiscal policy scenarios. An important issue highlighted in the EPA debate is the loss of tariff revenue following liberalization of imports from the EU given the high reliance of many ACP countries on this source of revenue (Bilal et al., 2012). In our simulations, the government balance is held constant (as otherwise the calculation of the welfare effects of the EPA would be distorted if the government were simply assumed to borrow to make up the lost tariff revenue thus passing the burden of financing current government spending 
Table 3: Import tariff scenarios for policy simulations

\begin{tabular}{|c|c|c|c|c|c|c|c|c|c|}
\hline & \multirow[t]{2}{*}{$\begin{array}{l}\text { Share in total } \\
\text { global imports }\end{array}$} & \multicolumn{3}{|c|}{$\begin{array}{l}\text { Share in sector's } \\
\text { imports }\end{array}$} & \multicolumn{3}{|c|}{$\begin{array}{l}\text { Weighted mean } \\
\text { tariff in } 2009\end{array}$} & \multicolumn{2}{|c|}{$\begin{array}{l}\% \text { change from } \\
2009 \text { EU tariff }\end{array}$} \\
\hline & & EAC & ROW & EU & EAC & ROW & EU & EPA & $\begin{array}{r}\text { EU free } \\
\text { trade }\end{array}$ \\
\hline Maize & 1.25 & 2.6 & 82.3 & 15.1 & - & 43.7 & 46.3 & 0.0 & -100.0 \\
\hline Rice* & 0.00 & - & 100.0 & - & - & 75.0 & - & - & - \\
\hline Other cereals & 4.11 & 5.7 & 86.7 & 7.6 & - & 23.4 & 23.3 & -1.3 & -100.0 \\
\hline Irish potatoes* & 0.00 & - & 100.0 & - & - & 25.0 & - & - & - \\
\hline Beans* & 0.39 & 3.5 & 68.4 & 28.1 & - & 25.0 & 25.0 & 0.0 & -100.0 \\
\hline Vegetables* & 0.18 & 65.5 & 14.3 & 20.2 & - & 12.6 & 0.4 & 0.0 & -100.0 \\
\hline Fruits & 0.03 & 44.9 & 55.1 & - & - & 24.8 & - & - & - \\
\hline Oil seed crops & 0.01 & 50.9 & 43.1 & 6.0 & - & 10.0 & 10.0 & - & - \\
\hline Cotton* & 0.01 & 98.8 & 1.2 & - & - & - & - & - & - \\
\hline Tobacco* & 0.04 & 4.1 & 95.9 & - & - & 25.0 & - & - & - \\
\hline Coffee* & 0.00 & - & 100.0 & - & - & 25.0 & - & - & - \\
\hline Tea leaves* & 0.00 & 67.0 & 27.8 & 5.2 & 1.9 & 25.0 & 25.0 & 0.0 & -100.0 \\
\hline Other export crops* & 0.00 & 90.8 & 5.1 & 4.0 & - & 25.0 & 25.0 & - & - \\
\hline Cattle* & 0.01 & 72.5 & 27.5 & - & - & - & - & - & - \\
\hline Poultry & 0.04 & 37.4 & 28.7 & 33.9 & - & 6.6 & 13.4 & -14.1 & -100.0 \\
\hline Other livestock* & 0.03 & 1.6 & 98.4 & - & - & 17.6 & - & - & - \\
\hline Forestry* & 0.02 & 90.1 & 9.0 & 0.9 & - & 0.1 & - & - & - \\
\hline Fish* & 0.04 & 0.6 & 50.4 & 49.1 & - & 25.0 & 25.0 & -99.6 & -100.0 \\
\hline Grain milling & 2.30 & 11.4 & 80.6 & 8.0 & 0.0 & 58.1 & 43.6 & -0.5 & -100.0 \\
\hline Meat processing & 0.25 & 35.4 & 39.3 & 25.3 & 0.6 & 49.9 & 55.4 & -0.4 & -100.0 \\
\hline Fish processing & 0.04 & 6.1 & 81.7 & 12.2 & - & 25.0 & 24.9 & -0.4 & -100.0 \\
\hline Other food processing & 6.49 & 18.2 & 75.3 & 6.5 & 0.5 & 28.9 & 26.3 & -1.8 & -100.0 \\
\hline Animal feed processing* & 0.01 & 35.9 & 22.8 & 41.3 & - & 10.0 & 10.0 & -91.6 & -100.0 \\
\hline Beverages \& tobacco & 0.31 & 75.3 & 17.1 & 7.6 & 1.3 & 23.5 & 25.0 & 0.0 & -100.0 \\
\hline Textiles \& clothing & 5.64 & 20.6 & 76.1 & 3.2 & 0.3 & 23.7 & 22.4 & -6.2 & -100.0 \\
\hline Wood \& paper products & 4.77 & 25.2 & 43.0 & 31.8 & 0.2 & 11.5 & 9.2 & -54.8 & -100.0 \\
\hline Mining & 0.86 & 83.7 & 15.2 & 1.1 & - & 3.1 & 7.8 & -48.9 & -100.0 \\
\hline Fuels & 13.66 & 97.8 & 2.2 & - & - & 9.0 & - & - & - \\
\hline Chemicals \& fertilizer & 16.43 & 16.2 & 58.0 & 25.8 & 0.3 & 5.9 & 3.3 & -41.6 & -100.0 \\
\hline Other manufacturing & 15.46 & 26.9 & 58.4 & 14.7 & 0.8 & 17.6 & 23.3 & -13.9 & -100.0 \\
\hline Machinery \& equipment & 27.12 & 4.3 & 62.8 & 32.9 & 0.0 & 10.4 & 4.1 & -70.6 & -100.0 \\
\hline Furniture & 0.49 & 11.9 & 74.2 & 13.8 & 0.0 & 24.8 & 25.0 & -22.8 & -100.0 \\
\hline Total or weighted average & 100.00 & 26.8 & 54.5 & 18.7 & 0.5 & 16.9 & 8.8 & -29.1 & -100.0 \\
\hline
\end{tabular}

Source: Own computation from the UNCTAD TRAINS database. "*” denote commodities which are not imported according to the SAM and thus will not be shocked in the model. 
on to future generations). In the default tariff scenarios, the lost tariff revenue is assumed to be restored using a hypothetical distribution-neutral uniform levy on all income sources including non-marketed production. This heuristic device is used to allow the impact effects of the tariff scenarios on income distribution and poverty to be calculated. It is obviously not a practical alternative; the way the government responds to the loss of tariff revenue will have second-round distributional and poverty effects which could overwhelm the poverty impacts of the initial EPA shock (Cororaton and Cockburn, 2007) or Tarp Jensen and Tarp, 2005). To examine the potential importance of these second-round effects on the tariff scenario results, three alternative government response scenarios have been investigated. The sales tax scenario shows the results of increasing the sales tax as an alternative government revenue loss compensation instrument. Here, all existing sales tax rates increase uniformly by the same percentage. This implies that exemptions, poor compliance and the like are amplified and hence strong income distribution impacts are expected. Only consumers of marketed goods will be affected and the impact will be the stronger the higher the initial sales tax on the good consumed. The two other scenarios assume that the government forgoes the revenue and instead reduces either government consumption (excluding social spending which contributes directly to household welfare) (gov. cons.) or government savings (gov. sav.).

Alternative labor market specifications. In a study on labor markets in Sub-Saharan Africa (SSA), Kingdon et al. (2006) find evidence that wages and employment are flexible, reflected in the ability of wages to either rise or fall at any point in time and in the existence of the wage curve relationship. In countries like Uganda, wage rates in the informal sector have been able to decrease enough to absorb any surplus labor as in the 1990s the formal sector employment grew less than the labor force without increasing unemployment. But Kingdon et al. also emphasize that SSA labor markets are rigid in the sense that they exhibit a strong segmentation between sectors (formal and informal) and between firms. Thus, their evidence hints that all the different typical stylized labor market assumptions might apply to some labor market segments to some extent. In light of this varied picture, we assess the sensitivity of our results with respect to the assumption of a wage curve-governed unskilled labor market by examining two extreme alternatives. First, a surplus labor assumption, characterized by an unlimited supply of unskilled labor at a fixed real wage, i.e., perfectly elastic unskilled labor supply where only demand determines employment, is chosen. Second, a neoclassical labor market assumption (constant labor), characterized by a constant, perfectly inelastic unskilled labor supply where only wages adjust to clear the market is implemented. 


\subsection{Results}

In the following, first the results of the EPA and the EU free trade scenarios using the hypothetical income levy as the tariff revenue replacement instrument are reported with respect to their general economic and poverty impacts. Subsequently, these are compared to the impacts of the three fiscal policy options and the alternative labor market specifications. All results are discussed in reference to the synthetic 2009 baseline scenario derived from the pre-experiment.

EPA scenario. The EPA tariff cuts are relatively small, resulting in a drop of 0.5 percentage points in Uganda's global trade-weighted tariff compared to 2009. The initial impact is to lower prices of imported goods and to stimulate their demand. Additionally, producer costs are lowered where imports are used as intermediate inputs. Cheaper imports exert a downward pressure on domestic sales prices and increase incentives to shift production away from import-competing goods to, in particular, export goods. The main driving mechanism in the model with constant foreign savings is the terms of trade change due to the depreciation of the real exchange rate and the consequential increase in exports required to balance the trade account after the import tariff shock. The EPA scenario results in a marginally lower GDP at market prices (decrease by $0.02 \%$, see Table (4).

Tariffs are predominantly reduced for investment goods. The largest shock, equivalent to $53 \%$ of overall import tariff revenue loss from the EPA, is in machinery \& equipment (compare Table 3) with other larger tariff cuts concentrated in wood \& paper products, other manufacturing, and chemicals, leaving only $3 \%$ of the shock to other sectors including the agricultural ones. With the exception of demand for chemicals, only a small fraction of the demand for these named sectors originates from final household demand. Moreover, the forward linkages of these products to household consumption are very weak. Hence, the immediate impacts of the EPA tariff cuts predominantly affect prices for investment goods. As investment is fixed in real terms in the model closure, the decrease in prices of machinery \& equipment and other manufacturing has only a small, positive demand effect through the small fraction of demand from households and some indirect effects through their use as intermediate inputs. The more important mechanism whereby reduced investment prices transmit to private consumption is that now less savings are required to maintain the level of real investment (household savings decrease by $0.82 \%$ ), allowing households to devote a larger share of their income to consumption.

As cheaper imports crowd out domestic production to some extent, the tariff cutinduced increase in demand is offset by reduced incomes in the import-competing sectors. Increased imports cause the domestic currency to depreciate (nominal exchange rate 
Table 4: Macroeconomic results

\begin{tabular}{|c|c|c|c|c|c|c|c|c|}
\hline & 2009 & EPA & $\begin{array}{l}\text { EU free } \\
\text { trade }\end{array}$ & $\begin{array}{r}\text { Sales } \\
\operatorname{tax}\end{array}$ & $\begin{array}{l}\text { Gov. } \\
\text { cons. }\end{array}$ & $\begin{array}{l}\text { Gov. } \\
\text { sav. }\end{array}$ & $\begin{array}{r}\text { Surplus } \\
\text { labor }\end{array}$ & $\begin{array}{r}\text { Constant } \\
\text { labor }\end{array}$ \\
\hline GDP components & $\%$ of GDP & \multicolumn{7}{|c|}{$\%$ change from 2009} \\
\hline Private consumption & 75.22 & -0.03 & -0.06 & -0.06 & 0.19 & -0.03 & 0.10 & -0.04 \\
\hline Investments & 21.03 & 0.00 & 0.00 & 0.00 & 0.00 & 0.00 & 0.00 & 0.00 \\
\hline Government consumption & 13.47 & 0.00 & 0.00 & 0.00 & -1.19 & 0.00 & 0.00 & 0.00 \\
\hline Total absorption & 109.95 & -0.02 & -0.04 & -0.04 & -0.02 & -0.02 & 0.07 & -0.03 \\
\hline Exports & 15.37 & 0.47 & 1.88 & 0.40 & 0.60 & 0.49 & 0.63 & 0.46 \\
\hline Imports & -25.32 & 0.29 & 1.14 & 0.24 & 0.36 & 0.30 & 0.38 & 0.28 \\
\hline GDP at market prices & 100.00 & -0.02 & -0.04 & -0.04 & -0.02 & -0.02 & 0.07 & -0.03 \\
\hline Net indirect taxes & 9.07 & -0.25 & 0.08 & -0.34 & -0.16 & -0.25 & -0.14 & -0.26 \\
\hline GDP at factor cost & 91.16 & 0.00 & 0.02 & -0.01 & 0.00 & 0.00 & 0.10 & -0.00 \\
\hline Government revenue & Share in total & \multicolumn{7}{|c|}{$\%$ change from 2009} \\
\hline ROW transfers & 38.77 & 0.15 & 0.54 & -0.07 & 0.14 & 0.15 & 0.14 & 0.15 \\
\hline Direct taxes & 31.53 & 3.18 & 8.07 & -0.16 & 0.12 & 0.10 & 3.07 & 3.19 \\
\hline Import taxes & 9.96 & -9.97 & -25.45 & -10.19 & -9.87 & -9.96 & -9.90 & -9.98 \\
\hline Sales taxes & 19.74 & -0.05 & -0.06 & 5.02 & 0.08 & -0.05 & 0.06 & -0.05 \\
\hline Factor income distribution & Share in total & \multicolumn{7}{|c|}{$\%$ point change from 2009 share } \\
\hline Labor unskilled & 38.75 & 0.01 & 0.04 & 0.00 & -0.00 & 0.01 & 0.01 & 0.01 \\
\hline Labor skilled & 13.26 & -0.00 & 0.00 & 0.00 & -0.04 & 0.00 & -0.01 & 0.00 \\
\hline Land & 8.11 & -0.01 & -0.02 & -0.00 & 0.02 & -0.01 & 0.01 & -0.01 \\
\hline Capital & 39.87 & -0.00 & -0.01 & -0.00 & 0.02 & -0.00 & -0.01 & -0.00 \\
\hline Closure variables & & \multicolumn{7}{|c|}{ change from 2009} \\
\hline Real exchange rate $(\%)$ & & 0.14 & 0.47 & 0.13 & 0.14 & 0.14 & 0.13 & 0.14 \\
\hline $\begin{array}{l}\text { Nominal exchange rate }(\% \text {, } \\
\text { UGX/USD) }\end{array}$ & & 0.15 & 0.54 & -0.07 & 0.14 & 0.15 & 0.14 & 0.15 \\
\hline Sales tax $(\%)$ & & 0.00 & 0.00 & 5.15 & 0.00 & 0.00 & 0.00 & 0.00 \\
\hline Income levy (\% point) & & 0.17 & 0.44 & 0.00 & 0.00 & 0.00 & 0.16 & 0.18 \\
\hline Savings (\%) & & -0.82 & -1.85 & -0.74 & -0.99 & 1.46 & -1.01 & -0.81 \\
\hline
\end{tabular}

Source: Own computation. 
increases by $0.15 \%$ ) which leads to rising domestic prices for exports and thus to a shift towards export sectors (imports increase by $0.29 \%$ and exports by $0.47 \%$ ). As the initial demand effect and its associated multiplier effects are small and there is additional leakage through increased taxes (the uniform income levy increases by 0.17 percentage points) to compensate for the government revenue loss (import tariff revenue decreases by $9.97 \%$ ), the export effects are not large enough to compensate the crowding out effects in the import-competing sectors. This is also reflected in total absorption decreasing by $0.02 \%$.

Although imports increase in total $(0.29 \%)$ and thus additional trade is created, imports from the EU increase more strongly (15.41\%) indicating that also some trade is diverted away from other exporters. Imports from the EAC decrease by $1.86 \%$, which is a non-welfare-reducing correction as within-EAC tariffs are zero, and from the ROW by $4.91 \%$ which likely includes some welfare-reducing trade diversion.

The detailed sector results on output, exports, imports, household consumption, and consumer prices are summarized in Table 5. The shift towards exports benefits mainly the fish, cash crop, fish processing, other food processing and tourism-related sectors which expand production in the order of $0.2 \%$ to $0.7 \%$. Wood \& paper products $(-3.1 \%)$, machinery \& equipment $(-1 \%)$, and chemicals \& fertilizer $(-0.4 \%)$ sectors are the only sectors with a noteworthy fall in production. These are among the main import sectors; faced with substantial tariff reductions of $42 \%$ to $71 \%$, imports crowd out domestic production. The exchange rate depreciation required to balance the external account means that imports decrease in most sectors apart from wood \& paper products $(+3.1 \%)$, machinery $\&$ equipment $(+0.7 \%)$, chemicals \& fertilizer $(+0.4 \%)$, and furniture and poultry (each $+0.3 \%$ ) where large tariff reductions are concentrated. Exports increase in all sectors except wood \& paper products $(-2.1 \%)$. Consumer prices increase for all food products except processed fish and for all services but prices for some manufactured goods decline. This is also reflected in household consumption which drops across all sectors apart from some manufacturing ones.

The slight contraction in economic activity, the decline in private consumption, and the rise in food prices suggest a deterioration of the income situation for the poor population. The effects on poverty are assessed based on the changes in real PCE of individual households which is determined, first, by its disposable income and, second, by the prices for its consumption. Apart from transfers, a household's income depends on the quantities of the factors it owns, their prices, and the extent to which these are employed. For skilled and unskilled labor the assumed wage curve mechanism allows employment to vary to some extent but the individual degree of labor utilization of each household $(68.3 \%$ and $76.6 \%$ on average of rural and urban poor's unskilled labor, respectively, see Table 2) determines to what extent it participates in the general labor supply changes. The income 
Table 5: Simulation results: Percentage changes from 2009 for the EPA scenario

\begin{tabular}{|c|c|c|c|c|c|}
\hline & Output & Exports & Imports & $\begin{array}{r}\text { Household } \\
\text { consumption }\end{array}$ & $\begin{array}{r}\text { Consumer } \\
\text { prices }\end{array}$ \\
\hline Maize & 0.02 & 0.33 & -0.09 & -0.05 & 0.09 \\
\hline Rice & -0.03 & - & - & - & 0.11 \\
\hline Other cereals & 0.07 & 0.37 & 0.05 & -0.09 & 0.10 \\
\hline Cassava & -0.07 & - & - & -0.06 & 0.09 \\
\hline Irish potatoes & -0.07 & - & - & -0.04 & 0.09 \\
\hline Sweet potatoes & -0.07 & - & - & -0.05 & 0.10 \\
\hline Beans & 0.03 & 0.38 & - & -0.05 & 0.08 \\
\hline Vegetables & -0.04 & 0.92 & - & -0.04 & 0.07 \\
\hline Matooke & -0.05 & - & - & -0.04 & 0.05 \\
\hline Fruits & -0.05 & 0.44 & -0.14 & -0.05 & 0.08 \\
\hline Oil seed crops & 0.00 & 0.37 & -0.06 & -0.07 & 0.09 \\
\hline Cotton & 0.49 & 0.49 & - & - & - \\
\hline Tobacco & 0.41 & 0.42 & - & - & 0.08 \\
\hline Coffee & 0.26 & 0.26 & - & - & - \\
\hline Tea leaves & 0.30 & 0.30 & - & - & - \\
\hline Other export crops & 0.79 & 1.18 & - & - & -0.07 \\
\hline Cattle & -0.00 & - & - & - & 0.09 \\
\hline Poultry & -0.09 & 0.25 & 0.32 & -0.08 & 0.08 \\
\hline Other livestock & -0.08 & 0.18 & - & -0.11 & 0.10 \\
\hline Forestry & -0.03 & 1.37 & - & 0.12 & -0.12 \\
\hline Fish & 0.44 & 0.67 & - & -0.07 & 0.08 \\
\hline Grain milling & -0.03 & - & -0.08 & -0.08 & 0.09 \\
\hline Meat processing & -0.06 & 0.25 & -0.20 & -0.08 & 0.08 \\
\hline Fish processing & 0.65 & 0.98 & -0.19 & 0.01 & -0.02 \\
\hline Other food processing & 0.29 & 1.02 & -0.14 & -0.02 & 0.03 \\
\hline Animal feed processing & -0.05 & - & - & - & 0.05 \\
\hline Beverages \& tobacco & 0.07 & 0.64 & -0.13 & -0.00 & -0.00 \\
\hline Textiles \& clothing & 0.08 & 0.53 & -0.14 & -0.09 & 0.06 \\
\hline Wood \& paper products & -3.09 & -2.13 & 3.06 & 1.25 & -1.25 \\
\hline Mining & 0.15 & 0.79 & -0.08 & - & 0.05 \\
\hline Fuels & 0.35 & - & -0.06 & -0.14 & 0.13 \\
\hline Chemicals \& fertilizer & -0.44 & 0.15 & 0.38 & 0.18 & -0.19 \\
\hline Other manufacturing & -0.07 & 0.62 & -0.17 & 0.10 & -0.13 \\
\hline Machinery \& equipment & -0.99 & 0.51 & 0.71 & 0.72 & -0.86 \\
\hline Furniture & 0.04 & 1.09 & 0.33 & 0.17 & -0.21 \\
\hline Utilities & -0.06 & 0.10 & - & -0.08 & 0.08 \\
\hline Construction & -0.00 & - & - & 0.09 & -0.09 \\
\hline Trade services & 0.04 & - & - & -0.09 & 0.06 \\
\hline Hotels \& catering & 0.17 & 0.28 & - & -0.01 & 0.03 \\
\hline Transport services & 0.17 & 0.36 & -0.04 & -0.10 & 0.09 \\
\hline Communication services & -0.02 & 0.19 & -0.08 & -0.07 & 0.06 \\
\hline Financial \& banking services & 0.02 & 0.34 & -0.06 & -0.05 & 0.05 \\
\hline Real estate & -0.06 & - & - & -0.08 & 0.09 \\
\hline Other private services & -0.03 & 0.11 & -0.06 & -0.13 & 0.11 \\
\hline Public administration & -0.00 & - & - & - & 0.10 \\
\hline Education & -0.05 & - & - & -0.09 & 0.07 \\
\hline Health & -0.03 & - & - & -0.03 & 0.01 \\
\hline Community services & -0.07 & - & - & -0.07 & 0.03 \\
\hline Total & -0.01 & 0.47 & 0.29 & -0.02 & - \\
\hline
\end{tabular}

Household consumption is valued at market prices. Source: Own computation. 
left after deducing income taxes (amounting to $1 \%$ of income of the rural and urban poor) and household savings ( $4.2 \%$ and $18.5 \%)$, the rates of which are closure variables of the model, is the amount available for consumption, the PCE. Then, a household's real PCE is further influenced by the prices of purchased and own produced consumption items as reflected in the household-specific CPI. Table 6 presents the FGT indices constructed on basis of the real PCE.

Turning to the actual results, table 4 shows that total factor income (GDP at factor cost) remains constant but its distribution across factors shifts marginally to the benefit of unskilled labor (+0.01 percentage points in factor income share). Although the disposable part of income is increased by a reduction in savings of $0.82 \%$ (Table 4), overall, the real PCE of poor households decreases because of increases in the income levy of 0.17 percentage points and in food prices in the order of $0.05 \%$ to $0.11 \%$, resulting in an increase of the poor households'-specific CPI by 0.04 percentage points (Table 6).

Table 6: Simulation results: FGT poverty, Gini, CPI and employment indices

\begin{tabular}{|c|c|c|c|c|c|c|c|c|}
\hline & \multirow[b]{2}{*}{2009} & \multicolumn{7}{|c|}{ Point chagens from 2009} \\
\hline & & EPA & $\begin{array}{l}\text { EU free } \\
\text { trade }\end{array}$ & $\begin{array}{r}\text { Sales } \\
\text { tax }\end{array}$ & $\begin{array}{l}\text { Gov. } \\
\text { cons. }\end{array}$ & $\begin{array}{r}\text { Gov. } \\
\text { sav. }\end{array}$ & $\begin{array}{l}\text { Surplus } \\
\text { labor }\end{array}$ & $\begin{array}{r}\text { Constant } \\
\text { labor }\end{array}$ \\
\hline \multicolumn{9}{|l|}{ National } \\
\hline Headcount & 31.62 & 0.03 & 0.02 & -0.04 & -0.14 & 0.02 & -0.07 & 0.04 \\
\hline Gap & 9.39 & 0.01 & 0.01 & -0.00 & -0.04 & 0.02 & -0.02 & 0.01 \\
\hline Severity & 3.98 & 0.00 & 0.00 & 0.00 & -0.02 & 0.01 & -0.01 & 0.00 \\
\hline Poor's CPI & 100.00 & 0.04 & 0.09 & -0.05 & 0.08 & 0.04 & 0.06 & 0.04 \\
\hline Poor's Employment & 100.00 & 0.01 & 0.04 & -0.01 & 0.01 & 0.01 & 0.26 & 0.00 \\
\hline Gini & 43.83 & 0.01 & 0.01 & -0.00 & 0.00 & 0.02 & 0.00 & 0.01 \\
\hline \multicolumn{9}{|l|}{ Rural } \\
\hline Headcount & 34.89 & 0.04 & 0.02 & -0.05 & -0.16 & 0.04 & -0.09 & 0.05 \\
\hline Gap & 10.43 & 0.01 & 0.01 & -0.00 & -0.05 & 0.02 & -0.02 & 0.01 \\
\hline Severity & 4.44 & 0.00 & 0.00 & -0.00 & -0.02 & 0.01 & -0.01 & 0.01 \\
\hline Poor's CPI & 100.00 & 0.04 & 0.09 & -0.05 & 0.08 & 0.04 & 0.06 & 0.04 \\
\hline Poor's Employment & 100.00 & 0.01 & 0.04 & -0.01 & 0.01 & 0.01 & 0.26 & 0.00 \\
\hline \multicolumn{9}{|l|}{ Urban } \\
\hline Headcount & 14.14 & 0.00 & 0.00 & 0.00 & -0.04 & -0.07 & 0.00 & 0.00 \\
\hline Gap & 3.81 & -0.00 & -0.01 & 0.00 & -0.02 & 0.01 & -0.01 & 0.00 \\
\hline Severity & 1.56 & 0.00 & -0.00 & 0.00 & -0.01 & 0.01 & -0.01 & 0.00 \\
\hline Poor's CPI & 100.00 & 0.04 & 0.06 & -0.02 & 0.07 & 0.04 & 0.06 & 0.04 \\
\hline Poor's Employment & 100.00 & 0.02 & 0.05 & -0.02 & 0.01 & 0.02 & 0.26 & 0.00 \\
\hline
\end{tabular}

Source: Own computation. Poor's CPI and employment represent CPI and unskilled labor employment changes calculated over the population in poverty only.

The poverty impacts of the EPA as shown in Table 6 are generally very small. On the national level, the poverty headcount increases by 0.03 percentage points, corresponding to about 8,400 additional people below the poverty line, and the gap by 0.01 percentage points, while the poverty severity index remains unchanged. The effect is concentrated 
in rural areas where the poverty headcount and gap increase by 0.04 and 0.01 percentage points, respectively, while the severity index remains constant indicating that incomes of households close to the poverty line deteriorate. Poverty in urban areas is unaffected. Income inequality increases marginally according to the Gini index.

Particularly the poverty headcount index is sensitive to the position of the poverty line. To analyze the resilience of the poverty result with respect to the poverty line changes in poverty indices are recalculated, varying the poverty lines in the range from $50 \%$ to $200 \%$ of the initial poverty lines (in 10\% steps), and shown in Figure 1. The poverty headcount index curve of the EPA scenario is close to zero or increasing for the entire range of poverty lines considered. ${ }^{11}$ The poverty gap index consistently shows the poor's incomes falling further below the poverty line. It is evident that the incomes of the majority of the people around those poverty lines deteriorate in the EPA scenario and thus poverty is consistently aggravated even if marginally.

EU free trade scenario. The extensive list of sensitive products included in the EPA maintains the larger part of the protection against EU imports corresponding to $70.8 \%$ of the initial duties gathered from these imports. The free trade scenario examines whether a further, complete removal of tariffs against EU imports would limit or exacerbate the impact of the EPA scenario on the economy and the poorer population. The EU free trade scenario differs from the EPA scenario not only in magnitude of the tariff cuts, as the shock is four times the size of the EPA shock in terms of total tariff revenue loss, but also in the sectors affected. Although $70 \%$ of the tariff revenue loss still occurs in the four aforementioned sectors, $30 \%$ is now spread across other sectors which directly affect consumer prices and thus demand. GDP at market prices contracts twice as much as in the EPA scenario. The increases in imports and exports are four times and the falls in total absorption and private consumption are two times the size of those in the EPA scenario as the income levy increases by 0.44 percentage points, more than 2.5 times the increase of the EPA scenario, to compensate the correspondingly higher tariff revenue loss. Expansion of production is concentrated among the cash crop and fish-related sectors while the sectors wood \& paper and other manufacturing shrink strongly. Other manufacturing is an important import sector with $15 \%$ import share and EU imports are subject to a $23 \%$ tariff which is reduced by only about 3 percentage points in the EPA scenario.

Total factor income rises and lower investment prices require lower household savings but this is countered by the rise of the income levy and higher consumption prices for the poor (Table 6). In combination, these changes result in a 0.01 percentage points lower

\footnotetext{
${ }^{11}$ The jaggedness of the headcount index curve is caused by the presence of the binary variable in the FGT equation in combination with the fact that each household is weighted according to the number of individuals it represents nationally and by the clustering of households around certain PCE levels.
} 
Figure 1: Sensitivity of FGT poverty indices to the choice of the poverty line - EPA - - EU free trade - · Gov.cons.

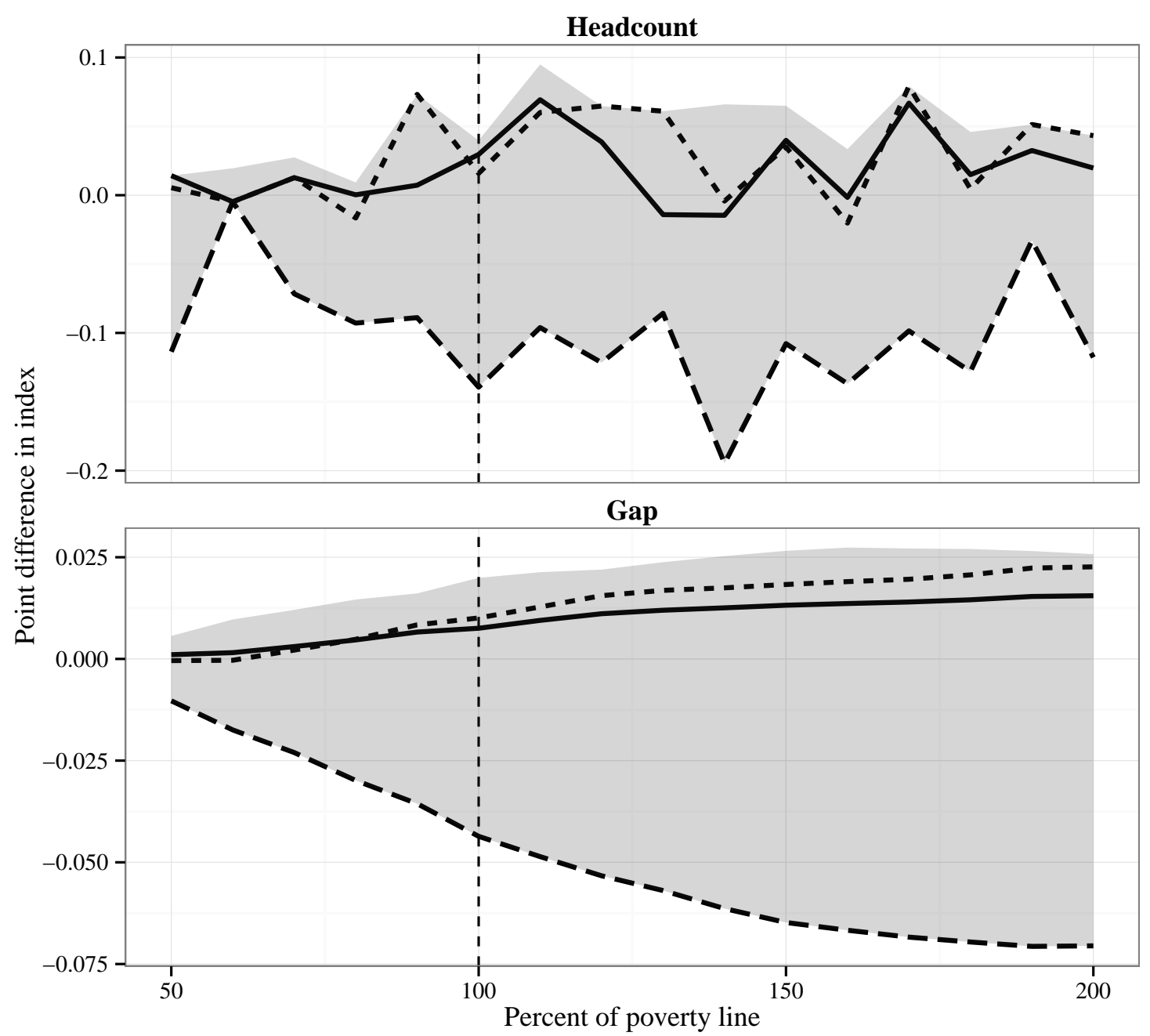

Source: Own computation. The shaded area represents the range of index result extremes over all scenarios simulated. 
poverty headcount (4,500 people) than in the EPA scenario. However, Figure 1 suggests that specifically households around the PCE level of the poverty line chosen are affected less negatively than in the EPA scenario but poverty is aggravated for other poverty lines in the range. The graph of the poverty gap index, by contrast, shows consistently that the EPA is more poverty friendly than the EU free trade scenario for all but the lowest poverty lines. The poverty gap measure indicates a marginal improvement for the poor urban households.

Fiscal policy scenarios. Increasing the sales tax as a compensatory measure for tariff revenue loss leads to stronger income distribution effects compared to the income levy in the default EPA scenario. The sales tax scenario assumes a uniform percentage increase of the existing, sector-specific sales tax rates which implies that incomes of households which consume high shares of goods and services from market sources rather than own produce and especially those with initially high sales taxes are affected the most. According to Table 2, poor and non-poor, rural and urban households contribute on average only around $1.4 \%$ of their income to sales taxes. Home produce accounts for $37.7 \%$ and $15.9 \%$ of the total consumption of the rural and urban poor, respectively (Table 2 ). Through the implementation of the EPA tariff cuts, tariffs drop but this initially benefits mainly prices in the investment goods sectors and thus investment demand. The benefit to households is a reduction in required savings. As the sectors with high levels of sales taxes tend to be consumption goods sectors, private consumption carries most of this additional sales tax burden. This subdues private consumption so that imports increase less compared to the EPA scenario while GDP and private consumption decrease twice as much $(-0.04 \%$ and $-0.06 \%$, respectively). Total factor income decreases by $0.01 \%$. However, prices tend to decrease, in particular for food, which accounts for $61.8 \%$ of rural and $54.1 \%$ of urban consumption. The resulting drop in the poor's CPI of 0.05 percentage points, together with the decrease in savings, is sufficient to lift 12,700 rural people out of poverty $(0.04$ percentage points). Urban poverty remains unaffected.

The government consumption scenario protects government social expenditure on health and education but assumes that the government reacts to the import tariff revenue loss by cutting its spending on public administration including defense causing government consumption to decrease by $1.2 \%$. As the intermediate inputs to public administration are manufactured goods and services, the backward linkage effects for poor households are small. Similarly, the larger part of government value added is spent on skilled labor and capital with only $24 \%$ of gross output representing returns to unskilled labor. Thus, negative impacts from reduced government demand on the income of poorer households are limited. Given constant rates of sales and income taxes and lower savings required to fund investment, households increase consumption by $0.2 \%$. Total absorption 
and GDP decrease by the same amount as in the main EPA scenario. Nevertheless, this policy benefits the poor population. Although the poor's CPI increases by 0.08 percentage points, the number of poor Ugandans decreases by 39,600 people or 0.14 and 0.04 percentage points in the headcount and gap indices, respectively. The benefits to the rural poor are several times larger than those of the urban poor.

The government savings scenario assumes that the government reacts to the reduced income by reducing saving. This forces households to increase savings by $1.46 \%$ to maintain the savings-investment balance when investment and foreign savings are fixed. The mechanism resembles the income levy of the EPA scenario. But in contrast to the income levy that is implemented as a percentage point change in the tax on all incomes, in this scenario household savings are scaled uniformly by the same percentage. Since savings are calculated after tax, the effects also depend on the households' individual tax rates. Households with initially higher savings contribute more strongly to aggregate national savings. As household saving rates are distributed rather independently of income (Table 2), a priori the direction of impact on the poor's PCE is ambiguous. Gini coefficientmeasured inequality increases by 0.02 points. The poverty indices are close to those of the EPA scenario but the urban headcount index decreases by 0.07 percentage points. However, increasing gap and severity indices suggest that this is due to peculiarities of the households near this particular poverty line and that overall, incomes of the urban poor deteriorate.

Labor market specification scenarios. The surplus labor and constant labor scenarios implement two extreme assumptions about the market for unskilled labor. The surplus labor scenario results in comparatively strong expansions of GDP by $0.07 \%$ and of private consumption by $0.1 \%$. As additional unskilled labor can be drawn into production activities at a constant wage without limit, there are no counteracting substitution effects with other factors. With prices for exports rising through the depreciation of the exchange rate, export sectors expand. Because unskilled labor wages are not rising, production costs especially in the exporting sectors increase less than in the other scenarios causing greater expansion. The positive income effect, especially for poor households with relatively large endowments of unskilled labor, overwhelms the negative effect of the increase in the income levy so that positive consumption multiplier effects emerge. Output in all sectors other than forestry, wood \& paper products, chemicals \& fertilizer, other manufacturing, and machinery \& equipment expands. GDP at factor cost increases by $0.1 \%$ and the factor income distribution shifts slightly to the benefit of land and unskilled labor. The national poverty headcount and gap indices drop by $0.07 \%$ (20,800 people) and $0.02 \%$, respectively, where the benefits are largely confined to rural households.

By contrast, the constant labor scenario assumes utilization of unskilled labor remain- 
ing constant and a fully flexible wage rate which clears the market. Thus, households cannot increase their labor supply but only benefit from higher wages. When demand for unskilled labor increases, the market equilibrium is restored by a rise in the wage alone leading to stronger wage increases and greater substitution by other factors than under the flexible labor supply scenario. This diminishes the positive income effect for unskilled workers. But GDP, absorption and poverty headcount worsen by 0.01 percentage points more than in the EPA scenario because there the wage curve assumes unemployment to be rather inelastic $(-0.1 \%)$ with respect to the real wage. The number of people in poverty increases by 11,300 .

\section{Conclusions}

This paper examines some of the concerns expressed by ACP countries when negotiating EPAs using Uganda as a case study. Uganda is classified as an LDC and would continue to benefit from duty-free access to the EU market under the EBA scheme. So, as regards the trade liberalization provisions of EPAs, the main impact will be to liberalize a proportion of EU imports into Uganda (excluding sensitive products) with implications for tariff revenue loss, greater competition in import-competing sectors and changes in relative prices. Our study has estimated the potential impacts of these changes on Uganda's economic structure and welfare, but also on poverty rates. Our findings suggest more nuanced conclusions on the impact of EPAs may be appropriate than is often found in the ongoing debate.

An analysis of the EU-EAC EPA tariff schedule shows that the economic shock caused by the EPA is expected to be small due to the EU's low share in imports, modest tariffs for these imports, the fact that the list of sensitive products in the EPA allows Uganda to retain the majority of its protection against the EU, and the length of time for the liberalization process which allows the Ugandan economy to slowly adjust to the increased import competition. The EPA shock is much smaller than the shock originating from the implementation of the EAC's common external tariff which significantly changed the structure of Uganda's protection and doubled the average trade-weighted import tariff. The analysis has been conducted using the 2009 interim EPA tariff liberalization schedule but we do not expect the results will be greatly modified when the final liberalization schedule in the 2014 comprehensive EPA is made public.

The simulation results show that the EPA will result in very small negative impacts on Ugandan GDP and private consumption. In the aftermath of Uganda's import tariff cuts, imports increase causing the exchange rate to depreciate and thereby exports to increase. The magnitude of the effects is in the order of a fraction of a percent for the aggregate level economic indicators. There are shifts in the production structure with the 
main export sectors expanding in the order of half a percent and non-food manufacturing sectors decreasing by up to $3 \%$. Food manufacturing, textiles and tourism-related sectors register gains. Imports from the EU increase by $15 \%$ while those from the ROW and, to a lesser extent, from the EAC decrease. As total imports only increase by $0.29 \%$, some trade diversion occurs which is the primary cause of the negative welfare effect in our model. The national poverty headcount increases marginally by $0.02 \%$, affecting only rural areas. The magnitude is rather insensitive to the choice of the poverty line. Private consumption is suppressed despite lower import prices because the government offsets its loss in tariff revenue amounting to about $1 \%$ of its total revenue by a 0.17 percentage point increase in a hypothetical general levy on all households' incomes.

Under the same assumptions, a complete removal of tariffs on EU imports amplifies the sectoral shifts (up to $+3 \%$ for export and $-8 \%$ for non-food manufacturing sectors) and leads to double the contraction of GDP and private consumption although value addition as measured by GDP at factor cost expands slightly. Compensating the around $2.5 \%$ loss in government revenue requires a 0.44 percentage point higher income levy. Measured by the poverty gap, the average income of the poor deteriorates slightly more than in the EPA scenario.

In the EPA debate, some analysts have identified the potential loss of tariff revenue as a significant negative downside of EPAs (Bilal et al., 2012). However, econometric studies by Baunsgaard and Keen (2010) and Waglé (2011) show that, even if low income countries have not been overly successful in recouping lost tariff revenue from domestic taxation in the short run, they have more than fully compensated in the long run. A paper by the International Monetary Fund (2005) concludes that Uganda was able to recover the lost revenue caused by the major trade reform which began in 1987 by a multitude of measures including consumption and income taxes. The study by Hisali (2012) indicates that the Ugandan government also might have options to increase tariff revenue substantially, for example, by decreasing ad hoc and discretionary reliefs from which the government loses $19 \%$ of import tax revenue. The device of using a hypothetical income levy to replace lost tariff revenue is intended to highlight the income distribution and poverty effects of the tariff liberalization scenarios alone. If more realistic scenarios of tariff revenue replacement are examined, the analysis shows that the replacement strategy chosen by the government can have additional, second-round effects on the economy and poverty.

Our simulations examined the impact of three alternative revenue replacement strategies, namely increasing existing sales taxes, cutting government public administration while protecting expenditure on health and education, and reducing government savings. While reducing government savings had effects very similar to the main EPA scenario, increasing sales taxes exacerbated the initial negative impacts of EPA trade liberalization on 
overall private consumption but decreased poverty. Finally, cutting government public administration had an overall positive effect increasing private consumption and decreasing poverty rates the most. This finding suggests that designing an appropriate tariff revenue replacement strategy may be able to mitigate or even reverse any initial negative effects of discriminatory EPA trade liberalization.

The range of uncertainty about the sign of the poverty impact of EPAs is widened if alternative assumptions are made about how the market for unskilled labor operates. The default assumption in the main simulations assumed the existence of a wage curve in which unskilled wages are assumed to be sensitive to the rate of unemployment but not perfectly so. Assuming a closure in which wages adjust to clear the market for unskilled labor at a constant level of unemployment tends to exacerbate the negative economy and poverty impacts of EPA trade liberalization. By contrast, if a Lewis-type closure assuming unlimited supplies of unskilled labor at a fixed wage is deemed appropriate for the Ugandan economy for some time to come, then the stimulus to economic activity from the depreciated exchange rate following liberalization would be sufficient to reverse the estimated negative impacts on the economy and poverty found in the default scenario.

In this paper, we only look at the consequences of tariff liberalization under the EUEAC EPA for Uganda. EPAs are meant to be deep and comprehensive free trade agreements, and include provisions in many other areas, including services, government procurement and other 'behind the border' policies, which are not captured in the simulations here. The EPA also improves on some exporting conditions as compared to the EBA arrangement by relaxing the rules of origin, in particular for fish products and textiles and clothing, which open opportunities for increased value addition (Ramdoo and Walker, 2010). Nonetheless, our results are useful because they set a minimum threshold for the positive gains from these other provisions if, overall, an EPA is to lower poverty in Uganda, as well as highlighting the importance for the poverty impact of the way the government responds to the loss of tariff revenue.

Overall, we conclude that the tariff provisions in the EU-EAC EPA will have only a minor impact on the Ugandan economy, government revenue and Uganda's poor population. Additionally, any such impacts will occur gradually over the long transition period until 2033 during which Uganda will experience significant structural change likely dwarfing the EPA effects estimated in this paper. ${ }^{12}$ We also emphasize the capacity of the government itself to influence the economy and poverty outcomes through appropriate design of its tariff revenue replacement strategy. The dynamic impacts of the other aspects of EPAs are likely to prove more important for poverty than the tariff provisions

\footnotetext{
${ }^{12}$ For example, the EU's share in imports to Uganda has declined from $18.8 \%$ in 2003 to $17.7 \%$ in 2009 and $10.8 \%$ in 2012 (UN comtrade database, accessed online 19 July 2013, http://comtrade.un. $\mathrm{org} / \mathrm{db} / \mathrm{l}$.
} 
which have attracted most attention to date.

\section{References}

Anderson, K. and van der Mensbrugghe, D. (2007). Effects of multilateral and preferential trade policy reform in Africa: The case of Uganda, The Journal of International Trade \& Economic Development 16(4): 529-550.

Babula, R. and Baltzer, K. (2007). Overview of quantitative analyses of Economic Partnership Agreements: market and revenue effects of liberalization of ACP barriers and enhanced EU market access, Part 1 of a survey produced for the Danish Parliament, Institute of Food and Resource Economics, Copenhagen.

Baunsgaard, T. and Keen, M. (2010). Tax revenue and (or?) trade liberalization, Journal of Public Economics 94(9-10): 563 - 577.

Benson, T., Mugarura, S. and Wanda, K. (2008). Impacts in Uganda of rising global food prices: The role of diversified staples and limited price transmission, Agricultural Economics 39(s1): 513-524.

Bilal, S., Dalleau, M. and Lui, D. (2012). Trade liberalisation and fiscal adjustments: The case of EPAs in Africa, Ecdpm discussion paper 137, ECDPM, Maastricht.

Bilal, S. and Rampa, F. (2006). Alternative (to) EPAs. Possible scenarios for the future ACP trade relations with the EU, Policy Management Report 11, ECDPM, Maastricht.

Blanchflower, D. G. and Oswald, A. J. (1995). The Wage Curve, Vol. 1 of MIT Press Books, The MIT Press, Cambridge, MA.

Bourguignon, F., da Silva, L. A. P. and Bussolo, M. (eds) (2008). The impact of macroeconomic policies on poverty and income distribution : macro-micro evaluation techniques and tools, The World Bank and Palgrave MacMillan, Washington, DC.

Boysen, O. (2012). A food demand system estimation for Uganda, IIIS Discussion Paper Series No. 396, Institute for International Integration Studies, Trinity College Dublin.

Boysen, O. and Matthews, A. (2010). Trade and poverty impacts for Uganda, in O. Morrissey (ed.), Assessing Prospective Trade Policy: Methods Applied to EU-ACP Economic Partnership Agreements, Routledge, London, chapter 5, pp. 105-131.

Busse, M. (2010). Revisiting the ACP-EU Economic Partnership Agreements - the role of complementary trade and investment policies, Intereconomics 45: 249-254. 
Bussolo, M. and Cockburn, J. (eds) (2010). Macro-Micro Analytics - A Guide to Combining Computable General Equilibrium and Microsimulation modelling frameworks, Vol. 3(1) of International Journal of Microsimulation.

Cockburn, J., Corong, E. and Cororaton, C. (2010). Integrated computable general equilibrium (CGE) micro-simulation approach, International Journal of Microsimulation 3(1): 60-71.

Cororaton, C. B. and Cockburn, J. (2007). Trade reform and poverty - lessons from the Philippines: A CGE-microsimulation analysis, Journal of Policy Modeling 29(1): 141163.

Curran, L., Nilsson, L. and Brew, D. (2008). The Economic Partnership Agreements: Rationale, misperceptions and non-trade aspects, Development Policy Review 26(5): 529553.

Dimaranan, B. V., McDougall, R. A. and Hertel, T. W. (2006). Behavioral parameters, in B. V. Dimaranan (ed.), Global Trade, Assistance, and Production: The GTAP 6 Data Base, Center for Global Trade Analysis, Purdue University.

European Commission (2009). Annex IIa, IIb, IIc, IId to the Agreement establishing a framework for an Economic Partnership Agreement between the European Community and its Member States, on one part, and the East African Community Partner States, on the other part, 3 April 2009, Document Number 17462/08 ADD 2, ADD 3, ADD 4, ADD5, European Commission, Brussels. Accessed online 1 August 2010, http: //www.acp-eu-trade.org/index.php?loc=epa/ESA.php.

European Commission (2012). Fact sheet on the Economic Partnership Agreements - The Eastern African Community (EAC), June 2012, European Commission, Brussels. Accessed online 27 July 2013, http://trade.ec.europa.eu/doclib/docs/ $2009 /$ january/tradoc_142194.pdf.

European Commission (2014). Overview of EPA negotiations, updated October 2014, DG Trade, European Commision, Brussels. Accessed online 3 December 2014, http: //trade.ec.europa.eu/doclib/html/144912.htm.

Fofana, I. and Cockburn, J. (2003). Microsimulations in computable general equilibrium: Procedures for analysing and reconciling data, Mimeo, CIRPÉE, Université Laval.

Fontagne, L., Laborde, D. and Mitaritonna, C. (2008). An impact study of the EU-ACP Economic Partnership Agreements (EPAs) in the six ACP regions, CEPII Working Paper 2008-04 (revised 2009), Centre d'Études Prospectives et d'Informations Internationales, Paris. 
Foster, J., Greer, J. and Thorbecke, E. (1984). A class of decomposable poverty measures, Econometrica 52(3): 761-66.

Hertel, T., Hummels, D., Ivanic, M. and Keeney, R. (2007). How confident can we be of CGE-based assessments of free trade agreements?, Economic Modelling 24(4): 611635.

Hertel, T. W. and Ivanic, M. (2005). Poverty and the WTO: Impacts of the Doha Development Agenda, Palgrave Macmillan, New York.

Hinkle, L. E. and Schiff, M. (2004). Economic Partnership Agreements between Sub-Saharan Africa and the EU: A development perspective, The World Economy 27(9): 1321-1333.

Hisali, E. (2012). Trade policy reform and international trade tax revenue in Uganda, Economic Modelling 29(6): 2144 - 2154.

Hurt, S., Lee, D. and Lorenz-Carl, U. (2013). The argumentative dimension to the EUAfrica EPAs, International Negotiation 18: 67-87.

International Monetary Fund (2005). Dealing with the revenue consequences of trade reform, The IMF Fiscal Affairs Department, Washington, DC.

Keeney, R. and Hertel, T. W. (2009). The indirect land use impacts of United States biofuel policies: The importance of acreage, yield, and bilateral trade responses, American Journal of Agricultural Economics 91(4): 895-909.

Kingdon, G., Sandefur, J. and Teal, F. (2006). Labour market flexibility, wages and incomes in Sub-Saharan Africa in the 1990s, African Development Review 18(3): 392427.

Löfgren, H., Harris, R. L. and Robinson, S. (2002). A standard computable general equilibrium (CGE) model in GAMS, Microcomputers in Policy Research 5, International Food Policy Research Institute (IFPRI), Washington, DC.

McCulloch, N., Winters, L. A. and Cirera, X. (2001). Trade Liberalization and Poverty: A Handbook, UK Department for International Development and the Centre for Economic Policy Research, London.

Milner, C., Morrissey, O. and McKay, A. (2005). Some simple analytics of the trade and welfare effects of Economic Partnership Agreements, Journal of African Economies 14(3): 327-358. 
Milner, C., Morrissey, O. and Rudaheranwa, N. (2000). Policy and non-policy barriers to trade and implicit taxation of exports in Uganda, The Journal of Development Studies 37(2): 67-90.

Nijkamp, P. and Poot, J. (2005). The last word on the wage curve?, Journal of Economic Surveys 19(3): 421-450.

ODI (2006). The potential effects of Economic Partnership Agreements: What quantitative models say, Briefing paper 5, Overseas Development Institute, London.

Oxfam (2006). Unequal partners: How EU-ACP Economic Partnership Agreements could harm the development prospects of many of the world's poorest countries, Oxfam Briefing Note September 2006, Oxfam.

Ramdoo, I. and Walker, A. (2010). Implementing the Economic Partnership Agreement in the East African Community and the CARIFORUM regions: What is in it for the private sector?, ECDPM discussion paper 104, ECDPM, Maastricht.

Robinson, S., Cattaneo, A. and El-Said, M. (2001). Updating and estimating a social accounting matrix using cross entropy methods, Economic Systems Research 13(1): 4764.

Robinson, S. and El-Said, M. (2000). GAMS code for estimating a social accounting matrix (SAM) using cross entropy methods (CE), TMD discussion papers 64, International Food Policy Research Institute (IFPRI), Washington, DC.

Tarp Jensen, H. and Tarp, F. (2005). Trade liberalization and spatial inequality: a methodological innovation in a Vietnamese perspective, Review of Development Economics 9(1): 69-86.

Thurlow, J. (2008). A 2007 social accounting matrix for Uganda, Report, International Food Policy Research Institute (IFPRI), Washington, DC.

UBOS (2006). Uganda National Household Survey 2005/06 - report on the socioeconomic module, Uganda Bureau of Statistics, Kampala, Uganda.

UNCTAD (2010). UNCTAD TRAINS database, United Nations Conference on Trade and Development, Geneva, Switzerland. Accessed online on 22 November 2010, http: //wits.worldbank.org.

Vollmer, S., Martinez-Zarzoso, I., Nowak-Lehmann D., F. and Klann, N.-H. (2009). EUACP Economic Partnership Agreements: Empirical evidence for Sub-Saharan Africa, World Development Report 2009 - Background Papers, World Bank, Washington, DC. 
Vos, R., Ganuza, E., Morley, S. and Robinson, S. (eds) (2006). Who Gains from Free Trade: Export-Led Growth, Inequality and Poverty in Latin America, Routledge, New York and London.

Waglé, S. (2011). Coordinating tax reforms in the poorest countries - can lost tariffs be recouped?, Policy Research Working Paper 5919, The World Bank, Washington, DC.

Winters, A. (2008). Making the Economic Partnership Agreements more poverty friendly, Journal of International Trade and Diplomacy 2(2): 1-25.

Winters, L. A., McCulloch, N. and McKay, A. (2004). Trade liberalization and poverty: The evidence so far, Journal of Economic Literature 42(1): 72-115.

World Bank (2010). World Development Indicators. Accessed online 30 March 2011 at http://databank. worldbank.org/ddp/home.do?Step=12\&id=4\&CNO=2. 


\section{Appendix}

The appendix presents additional details about the model and the data used. More specifically, Appendix A contains the equations for the modifications applied to the IFPRI Standard CGE model. Appendix B describes further details on the household data derivation, SAM modification, elasticity parameters and tariff scenario construction.

\section{A Modifications to the IFPRI Standard CGE Model}

The following equations are added to the standard IFPRI CGE model documented in Löfgren et al. (2002).

\section{A.1 Land supply model formulation}

The nested CET land supply is implemented through the following four sets of equations.

$$
\begin{aligned}
& Q F_{f s}^{L 1}=\left(\sum_{a \in A_{s}} \delta_{f a}^{L 1} Q F_{f a}^{\rho_{f s}^{L 1}}\right)^{\frac{1}{\rho_{f s}}} \quad \forall s \in S, f \in F^{\prime} \\
& W F_{f} \cdot W F D I S T_{f a}=\frac{W F_{f s}^{L 1} Q F_{f s}^{L 1} \delta_{f a}^{L 1} Q F_{f a}^{\rho_{f s}^{L 1}-1}}{\sum_{a^{\prime} \in A_{s}} \delta_{f a^{\prime}}^{L 1} Q F_{f a^{\prime}}^{\rho_{f s} 1}} \quad \forall s \in S, a \in A_{s}, f \in F^{\prime} \\
& Q F_{f}^{L 0}=\left(\sum_{s \in S} \delta_{f s}^{L 0}\left(Q F_{f s}^{L 1}\right)^{\rho_{f}^{L 0}}\right)^{\frac{1}{\rho_{f}^{L 0}}} \\
& \forall f \in F^{\prime} \\
& W F_{f s}^{L 1}=\frac{W F_{f}^{L 0} Q F_{f}^{L 0} \delta_{f s}^{L 0}\left(Q F_{f s}^{L 1}\right)^{\rho_{f}^{L 0}-1}}{\sum_{s^{\prime} \in S} \delta_{f s^{\prime}}^{L 0}\left(Q F_{f s^{\prime}}^{L 1}\right)^{\rho_{f}^{L 0}}} \quad \forall s \in S, f \in F^{\prime}
\end{aligned}
$$

with $F^{\prime}$ : set of sluggish factors, $S$ : set of activity groups, $A_{s}$ : set of activities in group $s, \delta_{f a}^{L 1}$ and $\delta_{f s}^{L 0}$ : CET share parameters for the nests at level 1 and 0 , respectively, $\rho_{f s}^{L 1}=$ $1-\frac{1}{\sigma_{f s}^{L 1}}$ and $\rho_{f}^{L 0}=1-\frac{1}{\sigma_{f}^{L 0}}$ : CET exponent parameters, $\sigma_{f s}^{L 1}$ : elasticity of transformation within activity group $s$ of factor $f$, and $\sigma_{f}^{L 0}$ : elasticity of transformation between activity groups of factor $f .{ }^{13}$

For all factors in $F^{\prime}, W F_{f}$ is constant and $W F D I S T_{f a}, W F_{f s}^{L 1}, W F_{f}^{L 0}, Q F_{f s}^{L 1}, W F_{f}^{L 0}$ are variable. $Q F_{f s}^{L 1}$ and $Q F_{f}^{L 0}$ are "artificial" quantities and are ultimately restricted through the underlying factor demand quantities $Q F_{f a}$ in conjunction with the supply demand balance equation for factors (Löfgren et al., 2002, Eq. (39)).

\footnotetext{
${ }^{13}$ Elasticities are given as negative numbers.
} 


\section{A.2 Labor supply according to the wage curve and household-specific supply potentials}

The labor markets in the model implement the empirically founded wage curve relationship. In addition, for each household it is respected whether a household has additional potential for supplying labor and whether it has potential to further reduce labor supply, respectively, according to its current labor utilization status.

$$
\begin{aligned}
& Q F S_{f}=\sum_{H} Q F S H_{f, h} \quad \forall f \in F \\
& U E R_{f, h}=u e r 0_{f, h}+U E R A D J_{f} \\
& +U E R \_L T 0_{f, h}-U E R \_G T 1_{f, h} \quad \forall f \in F, h \in H \\
& U E R A D J_{f}=\left(\frac{Y F_{f} / Q F S_{f}}{Y F 0_{f} / Q F S 0_{f}} \cdot \frac{C P I 0}{C P I}\right)^{\epsilon^{f w c}}-1 \quad \forall f \in F \\
& Q F S H_{f, h}=q \operatorname{fshmax}_{f, h} \cdot\left(1-U E R_{f, h}\right) \quad \forall f \in F, h \in H \\
& \operatorname{qfshmax}_{f, h} \geq Q F S H_{f, h} \perp U E R \_L T 0_{f, h} \geq 0 \quad \forall f \in F, h \in H \\
& U E R_{f, h} \leq 1 \perp U E R \_G T 1_{f, h} \geq 0 \quad \forall f \in F, h \in H \\
& S H I F_{h, f}=\frac{Q F S H_{f, h}}{Q F S_{f}} \quad \forall f \in F, h \in H
\end{aligned}
$$

Total labor supply $Q F S$ is the sum of all household labor supplies. The underemployment rate $U E R$ is given by the initial underemployment rate uer 0 plus an underemployment rate adjustment factor $U E R A D J$. UERADJ is governed by the wage curve relationship where the elasticity of unemployment with respect to the real wage $\epsilon^{f w c}$ is assumed to equal -0.1. The higher the wage is the lower is unemployment. This affects all individual households' labor supply by an identical percentage point change. But each household's labor supply is limited from above by its full employment $\left(q f s h \max _{F, H}\right)$ and from below by unemployment $(U E R=0)$, implemented by the two complementarity conditions Eq. (A.9) and Eq. A.10. If a household's labor supply hits the maximum (full employment), then the variable $U E R \_L T 0$ adjusts to take the amount of excess employment while if the household's labor supply hits zero (no employment), then the variable $U E R \_G T 1$ adjusts to take the amount of excess unemployment. This means that each household's labor supply curve is vertical for wages leading to unemployment rates greater than one and employment rates less than zero. The area of underemployment is governed by the shape of the wage curve. Additionally, each household's share in a factor's income is not fixed any more but instead varies together with the household's factor supply and thus is calculated endogenously. 


\section{A.3 Differentiation of imports by origin}

In order to represent tariff cuts appropriately and to include the effects of trade diversion, imports have to be disaggregated by origin. To this end, the standard Armington formulation in the model, which aggregates imports and domestic production of a commodity, is complemented with an additional, second-level CES function (Eq. A.12). This CES function aggregates commodity imports from different regions of origin to a composite imported commodity that is then used in the standard Armington function. The corresponding first order condition for the optimum combination of imports from different regions derived from the CES function is given in Eq. (A.13) and the domestic price of commodity $c$ imported from region $r$ is defined in Eq. (A.14).

$$
\begin{array}{rlrl}
Q M_{c}= & \alpha_{c}^{q m} \cdot\left(\sum_{r \in R} \delta_{c r}^{q m} \cdot Q M R_{c r}^{-\rho_{c}^{q m}}\right)^{-\frac{1}{\rho_{c}^{q m}}} & & \forall c \in C M R \\
P M R_{c r}= & P M_{c} \cdot Q M_{c}\left(\sum_{r^{\prime} \in R} \delta_{c r^{\prime}}^{q m} \cdot Q M R_{c r^{\prime}}^{-\rho_{c}^{q m}}\right)^{-1} & \\
& \cdot \delta_{c r}^{q m} \cdot Q M R_{c r}^{-\rho_{c}^{q m}-1} & & \\
P M R_{c r}= & p w m r_{c r} \cdot\left(1+t m r_{c r}\right) \cdot E X R & & \\
& +\sum_{c^{\prime} \in C T} P Q_{c^{\prime}} \cdot i c m_{c^{\prime} c} & & \forall c \in C M R, r \in R
\end{array}
$$

where $C M R$ : set of regionally disaggregated imported commodities, $R$ : set of regions with disaggregated imports, $P M R_{c r}, Q M R_{c r}, t m r_{c r}$ : domestic price, quantity, and import tariff rate of imported commodity $c$ from region $r, \delta_{c r}^{q m}, \rho_{c}^{q m}$ : share parameter and function exponent for CES aggregation of imports of commodity $c$ from different origins $r$.

\section{B Data details}

\section{B.1 SAM modification}

To fully disaggregate the representative households of the original 2007 SAM, data on consumption expenditures and income sources for all 7,421 households is required and it needs to be consistent with the level of aggregation and the aggregate values of the corresponding accounts of this same SAM. Fofana and Cockburn (2003) and Cockburn et al. (2010) contain descriptions of similar undertakings which were helpful for parts of our procedure. This data work is based on the detailed socio-economic and agricultural questionnaire modules of the UNHS 2005/06, occasionally complemented by the 
2002/03 supply-use tables for Uganda. The included sample of 7,426 households corresponds to 40,449 individuals and is nationally representative, see UBOS (2006). Inflated by sample weights, the sample represents a population of 28,428,169 individuals. ${ }^{14}$ Due to incompleteness and inconsistency of the survey data, it has been cleaned and values imputed. The derivation of household consumption is relatively straightforward. With respect to household income, the survey contains a number of questions on occupation, labor hours, days of work, wages etc. which allow inference of hours worked per household by skill type (skilled, unskilled) and gender as well as what kind of work (crop, wage, self-employed non-agricultural) and further, the imputation of labor incomes. Questions on areas cultivated and land rents facilitate imputation of returns on land owned. Questions on household assets, financial assets and pensions serve to derive capital income.

After extracting the relevant information from the household survey, income for each household has been scaled to match expenditures plus savings. In the next step, the household values are multiplied by their sample weights and the aggregate values are compared to those from the SAM. Assuming that the aggregate values of income, expenditures, and savings from the SAM are more reliable, the household values are adapted to match the aggregates of the SAM. The procedure maintains the structure of income and expenditure of each household as well as the expenditure budget distribution. The value added of the initial SAM is split into the factor returns determined from the household data which are then used to modify the activity to factor payments as well as the factor to household payments. The total value added is maintained. As there is more certainty about factor to household payments than activity to factor payments as derived from the household survey, only the latter rows and columns are rebalanced keeping the factor to household payments fixed and adjusting the activity to factor payments. To rebalance the now unbalanced SAM, the information theory-based cross-entropy approach implemented and documented in Robinson and El-Said (2000) and Robinson et al. (2001) is utilized.

As this study focuses on household income distribution, the consumption structure for each household from the survey is imposed on the SAM. Hence, final demands for commodities change and thus production must adapt. This SAM is rebalanced by allowing only activity and commodity columns to adjust while holding fixed the import and tax rows as those are assumed to be reliable. Since the factor to household payments remain constant, also total payment to each factor remains fixed during the process. In the initial Uganda SAM households did not receive any transfers from other households or remittances from abroad although these are an important source of income for many households. As source and destination of the transfer flows between households are not known, they all pay to and receive from a common transfer account. In the model, the transfer outflows of households are fixed shares of their net disposable incomes and then the

\footnotetext{
${ }^{14}$ Five households had to be deleted due to missing data, leaving 7421 households.
} 
households receive fixed shares of the transfer account total. Home and market consumption are kept separate and in the model only market consumption is subject to transaction costs and taxes.

As described above, the CGE model distinguishes imports by origin between the EAC, the rest of the world (ROW), and the 27 countries comprising EU (EU). The original SAM's ROW import values are allocated to these three regions using 2003 values of imports from each region to Uganda taken from the TRAINS database (UNCTAD, 2010). The import tax revenue shares are calculated by trade-weighting the tariffs taken from this same database.

The structure of the final SAM is summarized in Table 1 More details on the household data processing is described in the following subsection.

\section{B.2 Household survey data preparation}

One of the main problems of integrating all households of a household survey into a CGE model are the vast data requirements. Household surveys suffer from incompleteness, inconsistency, and lack of the data which is required for a SAM. A SAM, on the other hand, needs to be complete and consistent by definition. Thus, the household survey data needs to be cleaned, completed using imputation, and corrected so that it is overall consistent. Additionally, expenditure items, industries, crops, etc. of the household survey have to be matched to the corresponding aggregates of the SAM. This section describes some crucial parts of the household data preparation which complement the information given in Section 3.2 .

Household expenditures are given in great detail and distinguish, in particular, between purchases, transfers and home consumption of own produce where home consumption is valued at farm gate prices. All non-home consumption is matched to SAM commodities and all home consumption to activities.

On the income side, the data preparation is much more involved. According to the structure of the SAM, households earn income from the factors of production (self-employed unskilled, wage-employed unskilled, skilled labor, land, and capital) and transfers. In particular, for household incomes from self-employment there is no clear-cut way of splitting the total value added between the factors as used in the SAM. Moreover, the sectors in which the household value added occurs are very important with regard to income distribution analysis as the change of factor returns through the change in sectoral structure is the main transmission mechanism of economic shocks to the households. 


\section{B.2.1 Factor to household payments}

As given in the different sections of the household survey, households get self-employment income from non-agricultural enterprises, crop agriculture, and livestock. Value added is derived from total revenue by subtracting the costs of intermediate and non-household factor inputs for all household enterprises. The total value added is then allocated to the different factors of production.

The allocation of the self-employment value added proceeds as follows. Labor is distinguished by skilled and unskilled where all workers in the categories one to three of the International Standard Classification of Occupations (ISCO) as used in the UNHS are defined to be skilled and all others unskilled. For unskilled labor, we assume that this is a surplus labor market governed by a fixed minimum wage at which more unskilled labor can be drawn into the labor market and below which laborers do not offer to work. This minimum wage for self-employed workers is approximated by the median hourly wage rate of the poorest $25 \%$ of households and separate wage rates are determined for person type (male, female, and child) as well as for rural and urban areas. By contrast, the labor market for skilled workers is assumed to clear through the wage rate while the supply is fixed and skilled workers switch freely between wage and self-employment. Thus, the hourly wage rate for self-employed skilled workers is approximated by the median hourly wage rate of skilled wage workers, distinguished again by person type as well as by rural and urban areas. For each individual worker the total hours worked as well as the hours worked for wages are available so that the difference is the number of hours of self-employed work. Using additionally the information from the survey on hours worked in crop agriculture by person type, assuming that all crop agriculture work is unskilled, the non-determined residual of self-employed work is non-agricultural enterprise and livestock work. Together with income from wages from unskilled and skilled labor, this allows to derive total income from self-employed unskilled labor, wageemployed unskilled labor and (self- and wage-employed) skilled labor, respectively, on household level.

Returns to land of each household are determined by the area of land in use for agriculture multiplied by the median land rent in the associated district plus any land rents received minus any land rents paid (in cash or in kind).

The residual of total self-employed value added minus self-employed labor and selfemployed land returns is then allocated to capital earned from self-employment. Additionally, households earn income from capital in the form of returns from financial assets and pensions and from imputed rents for owned or free housing. 


\section{B.2.2 Activity to factor payments}

\section{Value added from self-employment.}

The household's factor returns from self-employment are allocated to activities as follows. Land is assumed to be used only in agriculture. The share in total land used per crop has been derived in the previous step and is used to split the land returns across crop activities. Pasture land is allocated to livestock by the share of cattle, poultry, and other livestock value in total livestock value, respectively.

The value of crop labor by person type has been derived above and all self-employed labor in crop agriculture is assumed to be unskilled. The shares of labor by person type spent per plot can be derived from the survey. The survey information on the division of crops planted on each plot then allows allocating the labor returns to each crop.

The non-crop labor share of labor returns are allocated to the different non-agricultural and livestock household enterprises by their shares in total revenue of these activities.

Similarly, the share of capital in self-employment value added is distributed across activities by their shares in total revenue of self-employment activities. Only the imputed values of owned or free housing are directly attributed to the real estate activity.

\section{Value added from market employment.}

In particular, for wage labor in agriculture, there is only very rough information on the exact crop or livestock sector. This motivates to use the distribution of wage labor returns across sectors using the compensation of employees as given in the 2002/03 Uganda supply-use tables. These are scaled so that the total value matches the total value of skilled and unskilled wages as derived from the household survey. For each sector this value is then split into skilled and unskilled labor returns using the corresponding shares derived from the household survey data. Since, for instance, different crops are not distinguished in the industry codes of the household survey, the same skilled to unskilled labor shares are applied to all crops.

Market employed capital consists of the part of capital income the representative enterprise does not pay out to households and incomes from financial assets and pensions. The earlier is allocated across activities according to their shares in consumption of fixed capital as shown in the supply-use tables. The latter are assigned to the banking activity.

\section{Further processing.}

Then, the factor payments of each activity are scaled to match the total value added of the respective activity from the original SAM. Obviously, this procedure does not guarantee that the factor returns across activities add up to the total value of that factor paid to households and enterprises. This is corrected by the balancing procedure described in 
Section 3.2. As the main focus of this study is on income distribution analysis, this approach tries to maintain the structure of factor income of the households as well as to infer the structure of factor income sources by activity based on the evidence from the household survey. But in general, the allocation of value added to factors of production is to some degree arbitrary.

\section{B.2.3 Household labor supply potentials}

The UNHS provides only limited information on under- and unemployment. The weekly data in section hsec7a is used to derive data on an upper limit of weekly work hours if individuals state that they were not available for more work and their hours worked for the week amounted to less than 40 hours. Questions on unemployment and inactivity (unavailability for work) are also available from section hsec7a. Based on the information from other sections on the hours the household spent on wage work, crop work, and nonagricultural household enterprise activities, an additional labor supply potential is derived separate for the skill levels unskilled and skilled and for the person types male, female, and child. Given this data, the potential supply of additional labor hours is weighted by imputed wages for these different labor types.

When actual labor supply is reconciled with the SAM this also requires modification of the labor supply potential. On the individual level, the underemployment ratio is preserved for households which have at least some employment. For completely unemployed households, labor supply potential is scaled by the average change in labor potential of the employed households. Afterwards, the aggregate ratio of underemployment to employment is restored by scaling only the non-employed part of the labor supply potential.

\section{B.3 Elasticity parameters}

Additionally, the model requires parameters for the various behavioral functions. The CET elasticities are set for all agricultural, non-processed commodities, forestry, fish, as well as for mining and other food processing the CET elasticities are set to 5, for all other goods and services the CET elasticities are set to 2.5. The Armington elasticities of substitution between domestic and imported goods are taken from Hertel et al. (2007) and it is assumed that the elasticity of substitution between imports from different origins is twice the corresponding Armington elasticities. ${ }^{15}$ The elasticities of factor substitution have been adopted from the GTAP, see Dimaranan et al. (2006, Table 20.2). The elasticity values are summarized in Table B.1.

With respect to consumption parameters, a consistent set of LES parameters is derived for each individual household using the expenditure and consumption data from the

\footnotetext{
${ }^{15}$ A short discussion of this "rule of two" can be found in Hertel et al. (2007, footnote 16).
} 
extended SAM and estimates of Ugandan rural and urban demand systems, respectively, reported in Boysen (2012). First, expenditure elasticities of item groups in the demand system are matched to the SAM commodities. Then, for each household separately, price and income elasticities are calculated from the expenditure and consumption data and the estimated demand systems. As the estimated Quadratic Almost Ideal Demand Systems adopted from Boysen (2012) allow for much more flexible consumption behavior than the LES and they also refer to different product aggregates, the calculated elasticities cannot be directly used in this CGE model. To generate consistent LES parameter sets, the differences between the LES and the previously calculated elasticities are minimized using a generalized maximum entropy objective function subject to the theoretical constraints of the LES.

\section{B.4 Tariff scenario data}

The CGE model distinguishes imports from the EAC, the ROW, and the EU. This requires a separate set of tariffs is required for each of these regions. All import tariff scenarios are constructed carefully assuring that they are not biased by changes in the trade value composition across traded goods or across countries. This is accomplished by, on the one hand, weighting all tariffs with 2003 import values, on the other hand, by weighting each country group eligible for a different preferential tariff schedule separately. ${ }^{16}$ The 2003 values of imports from each tariff preference region to Uganda are taken again from the TRAINS database. The tariffs are constructed from the raw tariff data the TRAINS database provides for each existing preferential tariff schedule. Finally, the tariffs for the EPA scenario are taken from the interim EU-EAC EPA as of April 2009 (European Commission, 2009) and represent the tariffs at the end of the implementation period in 2033.

All data are presented in the Harmonized System nomenclature but as the nomenclature changed over time and data is provided at different levels of aggregation, the data is mapped such that it conforms to a common nomenclature which is chosen to be the 2002 version of the Harmonized System (HS) at the 6-digit tariff line level. First, the raw tariff data from TRAINS is often given at the 8-digit level. Because the trade values are given only at the 6-digit level, we approximate the 6-digit tariff by the simple average of the 8-digit lines included. Second, 2003 trade and tariff data is given in HS 2002 but the 2009 tariff data as well as the EPA tariff schedule are given in HS 2007 and thus have to

\footnotetext{
${ }^{16}$ As shown in TRAINS, the preferential schedules are "MFN duties (applied)", "Regional tariff preference (COMESA) for Ethiopia", "Regional tariff preference (COMESA) for Eritrea", "Regional tariff preference (EAC) for Kenya", "Regional tariff preference (EAC)for Tanzania", "Preferential tariff for COMESA country members of the FTA", and "Preferential tariff for EAC countries". The most beneficial tariff schedule is applied for each country.
} 
Table B.1: Elasticities

\begin{tabular}{|c|c|c|c|c|c|}
\hline SAM account & Sector & $\sigma_{T}$ & $\sigma_{Q}$ & $\sigma_{Q M}$ & Production \\
\hline cmaiz & Maize & 5.00 & 1.30 & 2.60 & 0.24 \\
\hline crice & Rice & - & - & - & 0.24 \\
\hline cocer & Other cereals & 5.00 & 1.30 & 2.60 & 0.24 \\
\hline ccass & Cassava & - & - & - & 0.24 \\
\hline cipot & Irish potatoes & - & - & - & 0.24 \\
\hline cspot & Sweet potatoes & - & - & - & 0.24 \\
\hline cbean & Beans & 5.00 & - & - & 0.24 \\
\hline cvege & Vegetables & 5.00 & - & - & 0.24 \\
\hline cmato & Matooke & - & - & - & 0.24 \\
\hline cfrui & Fruits & 5.00 & 1.85 & 3.70 & 0.24 \\
\hline coils & Oil seed crops & 5.00 & 2.45 & 4.90 & 0.24 \\
\hline $\operatorname{ccott}$ & Cotton & - & - & - & 0.24 \\
\hline ctoba & Tobacco & 5.00 & - & - & 0.24 \\
\hline ccoff & Coffee & - & - & - & 0.24 \\
\hline cltea & Tea leaves & - & - & - & 0.24 \\
\hline cflow & Other export crops & 5.00 & - & - & 0.24 \\
\hline ccatt & Cattle & - & - & - & 0.24 \\
\hline cpoul & Poultry & 5.00 & 1.30 & 2.60 & 0.24 \\
\hline coliv & Other livestock & 5.00 & - & - & 0.24 \\
\hline cfore & Forestry & 5.00 & - & - & 0.20 \\
\hline cfish & Fish & 5.00 & - & - & 0.20 \\
\hline cprgr & Grain milling & - & 2.00 & 4.00 & 1.12 \\
\hline cmeat & Meat processing & 2.50 & 3.85 & 7.70 & 1.12 \\
\hline cprfi & Fish processing & 2.50 & 2.00 & 4.00 & 1.12 \\
\hline cprfd & Other food processing & 5.00 & 2.00 & 4.00 & 1.12 \\
\hline cfeed & Animal feed processing & - & - & - & 1.12 \\
\hline cbvtb & Beverages \& tobacco & 2.50 & 1.15 & 2.30 & 1.12 \\
\hline ctext & Textiles \& clothing & 2.50 & 3.75 & 7.50 & 1.26 \\
\hline cwood & Wood \& paper products & 2.50 & 2.95 & 5.90 & 1.26 \\
\hline cmine & Mining & 5.00 & 0.90 & 1.80 & 1.26 \\
\hline cfuel & Fuels & - & 5.20 & 10.40 & 1.26 \\
\hline cchem & Chemicals \& fertilizer & 2.50 & 3.30 & 6.60 & 1.26 \\
\hline coman & Other manufacturing & 2.50 & 3.75 & 7.50 & 1.26 \\
\hline cmach & Machinery \& equipment & 2.50 & 4.05 & 8.10 & 1.26 \\
\hline cfurn & Furniture & 2.50 & 3.40 & 6.80 & 1.26 \\
\hline cutil & Utilities & 2.50 & - & - & 1.26 \\
\hline ccons & Construction & - & - & - & 1.68 \\
\hline ctrad & Trade services & - & - & - & 1.68 \\
\hline chotl & Hotels \& catering & 2.50 & - & - & 1.68 \\
\hline ctran & Transport services & 2.50 & 0.50 & - & 1.68 \\
\hline ccomm & Communication services & 2.50 & 0.50 & - & 1.26 \\
\hline cbank & Financial \& banking services & 2.50 & 0.50 & - & 1.26 \\
\hline creal & Real estate & - & - & - & 1.26 \\
\hline cosrv & Other private services & 2.50 & 0.50 & - & 1.26 \\
\hline cadmn & Public administration & - & - & - & 1.26 \\
\hline ceduc & Education & - & - & - & 1.2 \\
\hline cheal & Health & - & - & - & 1.26 \\
\hline $\operatorname{ccsrv}$ & Community services & - & - & - & 1.26 \\
\hline
\end{tabular}

The CET elasticities $\sigma_{T}$ define the elasticity of transformation between exported and domestically sold goods within domestic production. The Armington and CES elasticities $\sigma_{Q}$ and $\sigma_{Q M}$ define the elasticity of substitution between imported and domestically produced goods and the one between imports from different origins, respectively. The column "Production" shows the elasticities of factor substitution for the respective production sectors. 
be mapped back to HS 2002. The tariff line concordance to map from HS 2007 to 2002 is taken from WITS. ${ }^{17}$ According to this mapping, in some cases multiple HS 2007 lines are associated with a single HS 2002 line. Such HS 2007 lines are aggregated to the corresponding HS 2002 line by using 2008 trade values for the particular region if any trade occurred on these or using a simple average otherwise.

In the final step, the HS 2002 6-digit tariffs are aggregated to SAM sectors and the model import origins EAC, ROW, and EU by using 2003 import values for weighting as follows.

$$
\tau_{s r}=\frac{\sum_{p \in P_{r}} \sum_{l \in L_{s}} \tau_{p l} \cdot v_{p l}^{03}}{\sum_{p \in P_{r}} \sum_{l \in L_{s}} v_{p l}^{03}} \quad \forall s \in S, r \in R
$$

where $R$ : set of aggregate model import regions, $P_{r}$ : preferential tariff schedules included in aggregate region $r, S$ : set of SAM sectors, $L_{s}$ : set of HS 2002 6-digit tariff lines forming SAM sector $s, \tau$ : tariff, and $v^{03}: 2003$ import value.

\footnotetext{
${ }^{17}$ WITS, World Bank, accessed online on 18 November 2010.
} 